\title{
STANDARDISASI/KALIBRASI SUMBER-SUMBER BRAKHITERAPI Prosedur Standardisasi untuk Kalibrasi Sumber-Sumber Brakhiterapi Pada Laboratorium Dosimetri Standar Sekunder (SSDL) dan Rumah Sakit
}

\author{
Nazaroh
}

\begin{abstract}
Abstrak
Irradiasi dengan brakhiterapi kini dianggap bagian penting dari terapi kanker. Dengan perbaikan teknik lokalisasi dan sistem perencanaan, menyebabkan pemberian dosis lebih tepat dan akurat serta kedapatulangannya lebih baik. Tetapi hasil klinik yang dikehendaki hanya dapat dicapai dengan praktek klinik dan dosimetri yang baik, yaitu dengan mengimplementasikan program jaminan kualitas komprehensif yang meliputi prosedur kontrol kualitas secara rinci. Standar Keselamatan Dasar Internasional (International Basic Safety Standards) untuk proteksi terhadap radiasi pengion dan untuk keselamatan sumber radiasi telah menetapkan suatu prosedur kalibrasi sumber yang digunakan untuk paparan medik. Untuk sumber-sumber yang digunakan dalam brakhiterapi perlu kalibrasi yang tertelusur ke laboratorium dosimetri standar. Makalah ini membahas standardisasi atau kalibrasi sumber-sumber brakhiterapi dan kontrol kualitas pengukuran serta prosedur yang berkaitan dengan aspek keselamatan.
\end{abstract}

Kata kunci: kalibrasi, brakhiterapi, kontrol

\section{Abstract}

Irradiation with brachiterapy is nowadays assumed by important shares of cancer therapy. With the improved localization technique and treatment planning system, it is now possible to have precise, accurate and reproducible and dose delivery. However, the desired clinical result can only be achieved with a good clinical and dissymmetric practice that is with the implementation of a comprehensive quality assurance (QA) program which includes detailed quality control procedures. The International Basic Safety Standards for protection against Ionizing Radiation and the Safety of Radiation Sources has established a requirement on the calibration of sources used for medical exposure. For sources used in brachiterapy treatments, a calibration traceable to a Standards Dosimetry Laboratory is required. This report deals with the calibration of brachiterapy sources and related quality control (QC) measurements, safety aspect related to the calibration procedures.

Keywords: calibration, brakhiteraphy, control

\section{PENDAHULUAN}

Seperti kita ketahui bersama bahwa pancaran radiasi dapat mengionisasi atom bahan yang dilaluinya sehingga dapat mengakibatkan perubahan kimia dan biologi pada bahan tersebut. Oleh para pakar, sifat ini justru dimanfaatkan untuk berbagai aplikasi di bidang industri pengawetan makan, pertanian, kedokteran dan lain-lain. Di bidang kedokteran pancaran radiasi digunakan untuk diagnosa dan pengobatan (terapi) penyakit maligna (kanker).

Saat ini penyakit kanker menjadi salah satu penyebab kematian tertinggi di negara maju. Terapi penyakit kanker dengan menggunakan radiasi (radioterapi), kini sudah menjadi salah satu alternatif yang banyak diminati masyarakat. Secara sederhana, radioterapi didefinisikan sebagai pemanfaatan radiasi pengion untuk membunuh atau menghilangkan penyakit maligna dengan membatasi efek negatif seminimal mungkin terhadap jaringan sehat di sekitarnya [1].

Berdasarkan jarak sumber radiasi terhadap sel kanker, radioterapi dikategorikan ke dalam dua kelompok, yaitu teleterapi dan brakhiterapi. Brakhiterapi menggunakan sumber radiasi tertutup berukuran kecil yang diaplikasikan ke jaringan kanker.

Teknik brakhiterapi untuk terapi kanker gynaecologic wanita telah ada sejak penemuan radium. Tahun 1972, IAEA (International Atomic Energy Agency) bekerjasama dengan WHO (World Health Organization) membentuk kelompok kerja internasional untuk diagnosa dini dan terapi Carcinoma Cervix dengan negaranegara berkembang. Kelompok kerja ini mempromosikan penggunaan radionuklida ${ }^{137} \mathrm{Cs}$, ${ }^{60}$ Co dan ${ }^{192}$ Ir. Kini irradiasi dengan brakhiterapi dianggap bagian penting dari terapi kanker. Dengan perbaikan teknik lokalisasi dan sistem perencanaan menyebabkan pemberian dosis lebih tepat dan akurat serta kedapat ulangannya 
lebih baik. Tetapi hasil klinik yang dikehendaki hanya dapat dicapai dengan praktek klinik dan dosimetri yang baik, yaitu dengan mengimplementasikan program jaminan kualitas komprehensif yang meliputi prosedur kontrol kualitas secara detil.

Berdasarkan laju dosis yang diberikan pada sel kanker ada 3 kelompok, yaitu 0,4-2 Gy/jam adalah LDR (Low Dose Rate), 2-12 Gy/jam adalah MDR (Medium Dose Rate) dan lebih dari 12 Gy/jam adalah HDR (High Dose Rate) [2].

Brakhiterapi menggunakan sumber radioaktif berbentuk kapsul, jarum (hair-pin dan single-pin) atau tube, untuk menghantarkan dosis tinggi ke jaringan sel kanker. Bentuk terapi ini akan aman dan efektif manakala sumbersumber tersebut dikalibrasi atau distandarkan terlebih dahulu dan memiliki ketertelusuran terhadap standar internasional yang dapat diterima.

Untuk beberapa sumber brakhiterapi, penjual biasanya memberikan ketidakpastian nilai kalibrasi yang dinyatakannya sampai dengan $10 \%$. Kalibrasi atau standardisasi sumber brakhiterapi end-user (pengguna akhir) itu perlu, tidak hanya untuk memeriksa kalibrasi yang dinyatakan penjual tetapi juga untuk menjamin ketertelusuran ke standar internasional yang dapat diterima. Laporan dari kelompok kerja 40 AAPM (American Association of Physicist in Medicine) [3] menyatakan bahwa "Setiap institusi yang sedang merencanakan brakhiterapi harus mempunyai kemampuan untuk memeriksa kekuatan sumber yang dilengkapi oleh pabrik".

Laporan ini membahas teknik kalibrasi sumber-sumber brakhiterapi ${ }^{137} \mathrm{Cs},{ }^{192} \mathrm{Ir},{ }^{60} \mathrm{Co}$ dan ${ }^{125}$ I. Sebagai informasi bahwa penggunaan sumber brakhiterapi HDR ${ }^{60} \mathrm{Co}$ mulai berkurang, dan juga jumlah brakhiterapi menggunakan sumber HDR ${ }^{137} \mathrm{Cs}$ juga terbatas. Oleh sebab itu laporan ini menitikberatkan pada kalibrasi sumber-sumber brakhiterapi LDR ${ }^{137} \mathrm{Cs}$ dan HDR ${ }^{192}$ Ir.

Untuk kalibrasi sumber LDR ${ }^{137} \mathrm{Cs}$, laboratorium Dosimetri IAEA memelihara sumber-sumber acuan yang terkalibrasi pada PSDL (Primary Standard Laboratory Laboratory). Sumber-sumber tersebut dapat digunakan untuk mengkalibrasi Kamar Pengion Tipe Sumur yang dipelihara pada SSDL. Dilain pihak, PSDL tidak memiliki standar-standar untuk kalibrasi sumber HDR ${ }^{192} \mathrm{Ir}$. Untuk memperoleh ketertelusuran sumber-sumber tersebut, sumber harus dikalibrasi menggunakan teknik pengukuran di udara bebas. Kemudian sumber terkalibrasi tersebut digunakan untuk mengkalibrasi kamar pengion tipe sumur. Teknik ini dapat juga digunakan untuk kalibrasi sumber-sumber LDR ${ }^{192} \mathrm{Ir}$.

\subsection{Spesifikasi Sumber-sumber Brakhiterapi}

Besaran yang disarankan untuk spesifikasi sumber-sumber gamma adalah laju kerma udara acuan, yang didefinisikan oleh ICRU [4,5] sebagai laju kerma terhadap udara $(\mathrm{AKR}=\mathrm{Air}$ Kerma Rate), di udara, pada jarak acuan $1 \mathrm{~m}$, dikoreksi terhadap atenuasi dan hamburan. Untuk sumber radiasi berbentuk jarum, tube dan sumber padatan yang mirip, arah dari pusat sumber ke titik acuan harus pada sudut lurus ke sumbu panjang sumber. Satuan SI (Sistem Internasional), laju kerma udara acuan adalah Gy. $\mathrm{s}^{-1}$ tetapi pada prakteknya dapat digunakan $\mu G y . h^{-1}$ dan G $\mathrm{h}^{-1}$ untuk aplikasi HDR.

$$
\text { Banyak sistem perencanaan }
$$
menggunakan aktivitas sebagai besaran untuk spesifikasi sumber brakhiterapi. Jika sumber tersebut dikalibrasi dalam istilah lain, perlu dilakukan konversi.

Tabel 1. Konstanta Laju Kerma Udara untuk Sumber Brakhiterapi

\begin{tabular}{|c|c|rr|}
\hline No & Nuklida & Konstanta Laju Kerma Udara Gy.h $\mathbf{h}^{-1} \mathbf{M B q}^{-1} \mathbf{m}^{\mathbf{2}}$ \\
\hline 1 & ${ }^{60} \mathrm{Co}$ & 0,3 \\
2 & ${ }^{137} \mathrm{Cs}$ & 0,077 \\
3 & ${ }^{192} \mathrm{Ir}$ & 0,108 \\
4 & ${ }^{125} \mathrm{I}$ & 0,033 \\
\hline
\end{tabular}

Laju kerma udara acuan, dinyatakan dalam $\mu \mathrm{Gy} \cdot \mathrm{h}^{-1}$, dapat dikonversikan ke aktivitas menggunakan konstanta laju kerma udara yang disajikan pada Tabel 1. Aktivitas diberikan dalam MBq. Nilai-nilai dalam tabel tersebut disarankan oleh ICRU [5]. 


\section{KALIBRASI SUMBER ACUAN 137Cs PADA SSDL}

\subsection{Umum}

Pada bagian ini membahas prosedur kalibrasi sumber-sumber brakhiterapi ${ }^{137} \mathrm{Cs}$ pada Laboratorium Dosimetri IAEA dan SSDL. Ada dua pendekatan yang dapat dipertimbangkan untuk kalibrasi sumber-sumber tersebut dalam istilah laju kerma udara acuan. Pendekatan pertama menghendaki sumber-sumber acuan yang akan dikalibrasi oleh suatu laboratorium standar dan penggunaannya untuk mentransfer kalibrasi lewat kamar pengion tipe sumur. Pendekatan kedua, melakukan pengukuran dengan kamar pengion yang memiliki kalibrasi laju kerma udara yang tertelusur ke laboratorium standar. Metode yang pertama mirip dengan metode yang digunakan di USA dan beberapa negara bagian Eropa. Metode tersebut diadopsi oleh IAEA dan disarankan oleh konsultan dalam melengkapi layanan kalibrasi untuk sumbersumber LDR ${ }^{137} \mathrm{Cs}$, melalui jaringan kerja SSDL IAEA/WHO. Metode yang disarankan tersebut berdasarkan pada akuisisi sumber-sumber SSDL dan kamar pengion tipe sumur yang mirip dengan kepunyaan yang ada pada Laboratorium Dosimetri IAEA. Metode ini menghendaki SSDL untuk mengkalibrasi kamar pengion tipe sumurnya pada Laboratorium Dosimetri IAEA menggunakan sumber-sumber acuan IAEA.

Tahapan penetapan standardisasi/ kalibrasi sumber-sumber brakhiterapi LDR dari PSDL ke pengguna rumah sakit melalui Laboratorium Dosimetri IAEA adalah sebagai berikut:

- $\quad$ IAEA memiliki dua sumber brakhiterapi

${ }^{137} \mathrm{Cs}$, yang dikalibrasikan pada PSDL dalam istilah Laju Kerma Udara. Sumber tersebut bersama dengan kamar pengion tipe sumur, kamar pengion berbentuk bola dengan volume besar, dan elektrometer mendasari terbentuknya standar dosimetri brakhiterapi IAEA.

- SSDL memperoleh sumber yang tidak terkalibrasi dan kamar pengion tipe sumur, mirip kepunyaan IAEA. SSDL, sekurangkurangnya harus memiliki satu sumber dari setiap tipe radionuklida yang diperlukan untuk kalibrasi pemakai. Keseluruhan sistem tersebut akan mendasari terbentuknya standar dosimetri brakhiterapi SSDL.

- Kamar pengion tipe sumur SSDL dikalibrasi pada Laboratorium Dosimetri IAEA menggunakan standar dosimetri brakhiterapi IAEA.

- $\quad$ SSDL mengukur Laju kerma udara acuan dari sumbernya menggunakan kamar pengion yang telah dikalibrasi.

- SSDL mengkalibrasi sumber pengguna dan kamar pengion tipe sumur menggunakan sumber standarnya.

\subsection{Prosedur pada Laboratorium Dosimetri IAEA}

\subsubsection{Bahan}

\subsubsection{Sumber-sumber Brakhiterapi}

IAEA telah membeli dua tipe sumber brakhiterapi dari Amersham Internasional. Sumber tersebut adalah CDCSJ5 tipe tube dan CDC1100 tipe silinder. Spesifikasinya disajikan pada Tabel 2.

Tabel 2 Sumber Acuan Brakhiterapi pada Laboratorium Dosimetri IAEA

\begin{tabular}{|c|c|c|c|c|c|c|}
\hline RN & Tipe & Kode & Akt. MBq) & Kapsul mmSS & LMm & Dmm \\
\hline${ }^{137}$ Cs & tube & CDCSJ5 & 2313 & 0,5 & 20,0 & 2,65 \\
${ }^{137}$ Cs & Silinder & CDC1100 & 3700 & 0,5 & 8,0 & 3,20 \\
\hline
\end{tabular}

Sumber-sumber tersebut telah dikalibrasi dalam istilah Laju Kerma Udara Acuan pada NIST (National Institute for Standards and Technology), USA. Kalibrasi sumber-sumber tipe ini dikerjakan dengan perbandingan langsung terhadap sumber standar kerja menggunakan kamar pengion pada jarak 500 dan 1000 mm [ 6 ]. Sumber standar kerja NIST telah dikalibrasi di udara menggunakan cavity chamber NIST, kalibrasi absolut mirip dengan kalibrasi berkas luaran ${ }^{60} \mathrm{Co}$. Laju kerma udara (AKR) acuan dari sumber acuan IAEA diukur di NIST, dinormalisir ke tanggal 1 Mei 1996 yaitu 339 mGyh $^{-1}$ untuk sumber tipe CDC1100 dan 
190,5 mGyh $^{-1}$ untuk sumber tipe CDCSJ5, dengan ketidakpastian kurang dari $2 \%$ pada tingkat kepercayaan $95 \%$.

\subsubsection{Kamar Pengion dan Elektrometer}

IAEA juga membeli kamar pengion tipe sumur dan elektrometer untuk menstandarkan prosedur pengukuran dan melengkapi bantuan teknis ke SSDL. Kamar pengion tipe sumur, HDR-1000 plus dirancang di Universitas Wisconsin dan difabrikasi oleh Standard Imaging Inc. Diameter kamar $102 \mathrm{~mm}$, tinggi $156 \mathrm{~mm}$ dan volume aktif $254 \mathrm{~cm}^{3}$. Holdernya berdiameter $35 \mathrm{~mm}$, tinggi $121 \mathrm{~mm}$ dengan perbedaan diameter dalam untuk menyesuaikan dengan diameter sumber. Dinding kamar pengion luar terbuat dari aluminium dengan tebal $20 \mathrm{~mm}$. Kamar pengion memiliki lubang ventilasi untuk menjaga udara di dalam pada kondisi lingkungan. Elektrometer yang digunakan dengan kamar pengion tipe sumur adalah CDX-2000A, suatu alat digital portable dari Standard Imaging Inc.
Pengukuran di udara dilaksanakan menggunakan kamar pengion LS-01, dirancang oleh Austrian Research Centre dan oleh PTW, Jerman. Kamar pengion tersebut berbentuk bola dan memiliki volume $1000 \mathrm{~cm}^{3}$. Dinding kamar pengion terbuat dari resin polyacetal (delrin) dan tebalnya $3 \mathrm{~mm}$. Diameter luar dari volume pengumpul adalah $140 \mathrm{~mm}$. Elektroda pengumpul pusat berbentuk bola dan memiliki diameter $50 \mathrm{~mm}$. Terbuat dari Styrofoam dan dilapisi dengan grafit. Teflon digunakan sebagai materi insulasi. Arus kamar pengion yang diukur dalam orde beberapa piko ampere. Elektrometer Keithley -617 digunakan untuk pengukuran di udara. Elektrometer ini alat yang memiliki sensitivitas tinggi, dirancang untuk mengukur tegangan antara 10 mikro Volt dan 200 Volt, arus antara $0,1 \mathrm{fA}$ dan $20 \mathrm{~mA}$ dan muatan antara $10 f C$ dan $20 \mathrm{nC}$.

Untuk memudahkan penanganan, sumber dimuat dalam holder tube dari bahan Perspex. Sumber tersebut dilekatkan dalam holder menggunakan batang Perspex seperti tersaji pada Gambar 1.

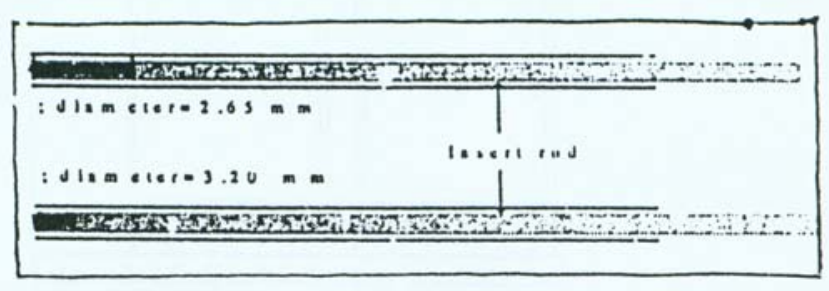

Gambar 1. Holder Sumber Perspex.

Sumber dimasukkan ke tabung Perspex panjang $150 \mathrm{~mm}$ dan dilekatkan pada posisi yang tetap.

\subsubsection{Metode}

\subsubsection{Standardisasi Pengukuran dengan Kamar Pengion Tipe Sumur}

Aspek penting dalam standardisasi pengukuran dengan kamar pengion tipe sumur adalah penentuan posisi optimal dari sumber dalam kamar pengion. Dengan posisi sumber pada titik ini, arus dimaksimalkan dan ketidakpastian dalam penentuan Laju kerma udara acuan akibat ketidakpastian posisi diminimalkan. Untuk penentuan posisi optimal, pengukuran dibuat dengan kamar pengion diposisikan di pusat ruangan (minimum jarak dari dinding 1,5 m) dan pada ketinggian $1 \mathrm{~m}$ dari lantai. Pengukuran muatan dilaksanakan pada berbagai posisi sumber sepanjang sumbu kamar dengan mengatur tinggi dari dasar sumur, disajikan pada Gambar 2.

Pada semua pengukuran, arus bocor mengkontribusi kurang dari 0,05\% terhadap muatan yang terkumpul. Variasi relatif tanggapan kamar pengion, dinormalisir thd nilai maksimum, ditunjukkan pada Gambar 3. Terlihat bahwa tanggapan maksimum dari kamar pengion tipe sumur diperoleh untuk sumber tipe CDCSJ5 (panjang total $20 \mathrm{~mm}$ ) adalah setinggi $39 \mathrm{~mm}$ dari dasar sumur, sedangkan untuk sumber tipe CDC1100 (panjang total $8 \mathrm{~mm}$ ) diperoleh tanggapan maksimum pada posisi $45 \mathrm{~mm}$ dari dasar sumur. Ini artinya bahwa tanggapan maksimum diperoleh ketika pusat sumber sekitar $50 \mathrm{~mm}$ dari dasar sumur. Tanggapan turun sekitar 0,5\% jika posisi sumber diangkat setinggi $9 \mathrm{~mm}$ dari posisi tanggapan maksimum. Untuk menjamin stabilitas waktu yang panjang dari set- 
up dan alat ukur, pengukuran dalam posisi optimal diulang selama periode waktu yang panjang. Tanggapan kamar dikoreksi terhadap kondisi temperatur dan tekanan lingkungan dan peluruhan sumber menggunakan ${ }^{137} \mathrm{Cs}$ yang memiliki waktu paro 30,17 tahun (1 tahun 365,25 hari). Kedapatulangan tanggapan kamar pengion setelah beberapa bulan disajikan pada Gambar 4 , yang terlihat variasinya dalam 0,5\%.

Faktor Kalibrasi Laju Kerma Udara Acuan dari kamar pengion tipe sumur, $\mathrm{N}_{\mathrm{KR}}$ ditentukan dari acuan [7]

$\mathrm{N}_{\mathrm{KR}}=\left(\mathrm{K}_{\mathrm{R}} \cdot \mathrm{t}\right) /\left(\mathrm{M}_{\mathrm{u}} \cdot \mathrm{k}_{\text {elekt }} \cdot \mathrm{k}_{\mathrm{Tp}} \cdot \mathrm{k}_{\mathrm{s}}\right)$

dimana:

$\mathrm{K}_{\mathrm{R}}$ : Laju Kerma Udara Acuan dari sumber tersebut

$\mathrm{M}_{\mathrm{u}}$ : bacaan elektrometer dari muatan yang terkumpul oleh kamar pengion tipe sumur dalam waktu t (bacaan skala).

kelekt: Faktor Kalibrasi Elektrometer (nC/bacaan skala)
kTp: Faktor Koreksi untuk temperatur dan tekanan pada waktu pengukuran

ks: Faktor Koreksi Rekombinasi

$\mathrm{k}_{\mathrm{Tp}}:(273,15+\mathrm{T}) /(293,15) \times(101,325 / \mathrm{p})$

\subsubsection{Standardisasi Pengukuran dalam Udara}

Pada prinsipnya kamar pengion tipe sumur hanya digunakan untuk tipe sumber yang telah dikalibrasi. Pada prakteknya, SSDL akan melengkapi kalibrasi tipe sumber yang berbeda ke pengguna rumah sakit. Pendekatan yang paling sesuai untuk menurunkan kalibrasi adalah membandingkan sumber yang akan dikalibrasi dengan standar acuan di udara pada jarak jauh, dimana perbedaan geometri antara dua tipe sumber tidak signifikan. Perbandingan laju kerma udara acuan dari sumber yang diberikan dengan perbandingan bacaan yang terkoreksi. Tujuan dari pengukuran di udara pada Laboratorium Dosimetri IAEA untuk menjamin akurasi dan kedapat-ulangan prosedur sebelum disarankan ke SSDL.

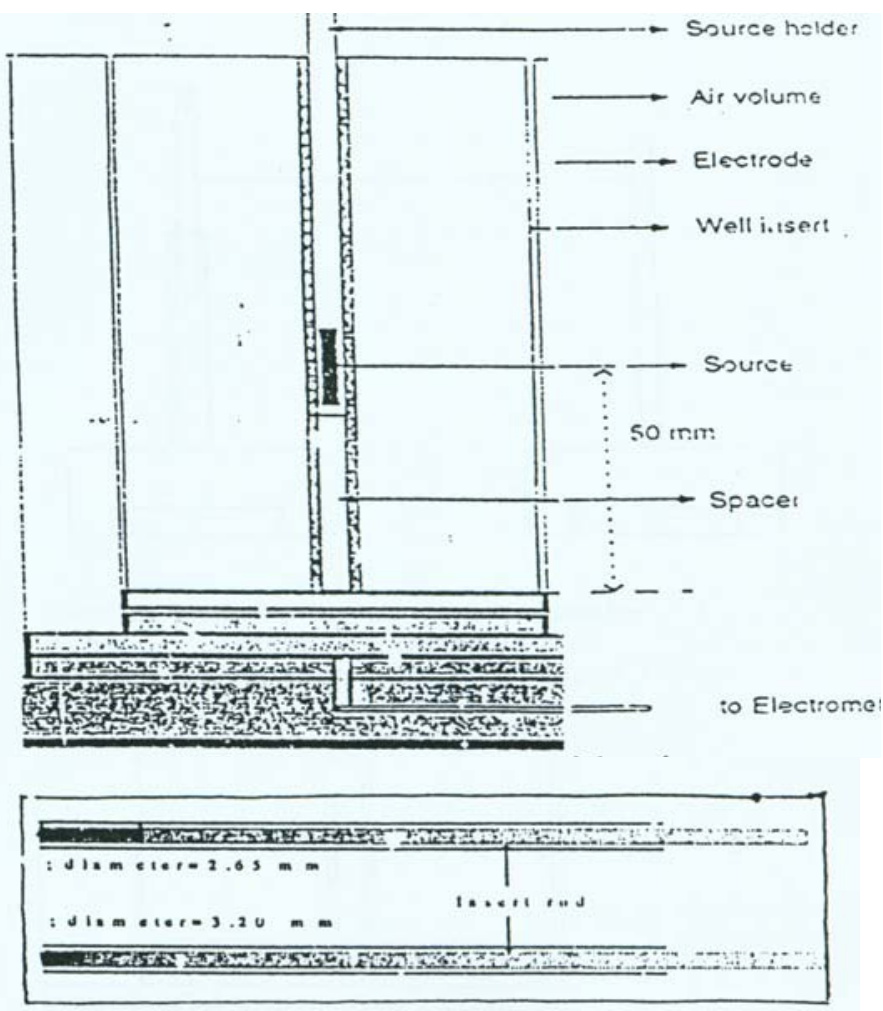

Gambar 2 Posisi Sumber dan Ruang Dalam Kamar Pengion.

Jarak $50 \mathrm{~mm}$ menunjukkan posisi optimum untuk sumber bila menggunakan kamar pengion tipe sumur milik laboratorium dosimetri IAEA 


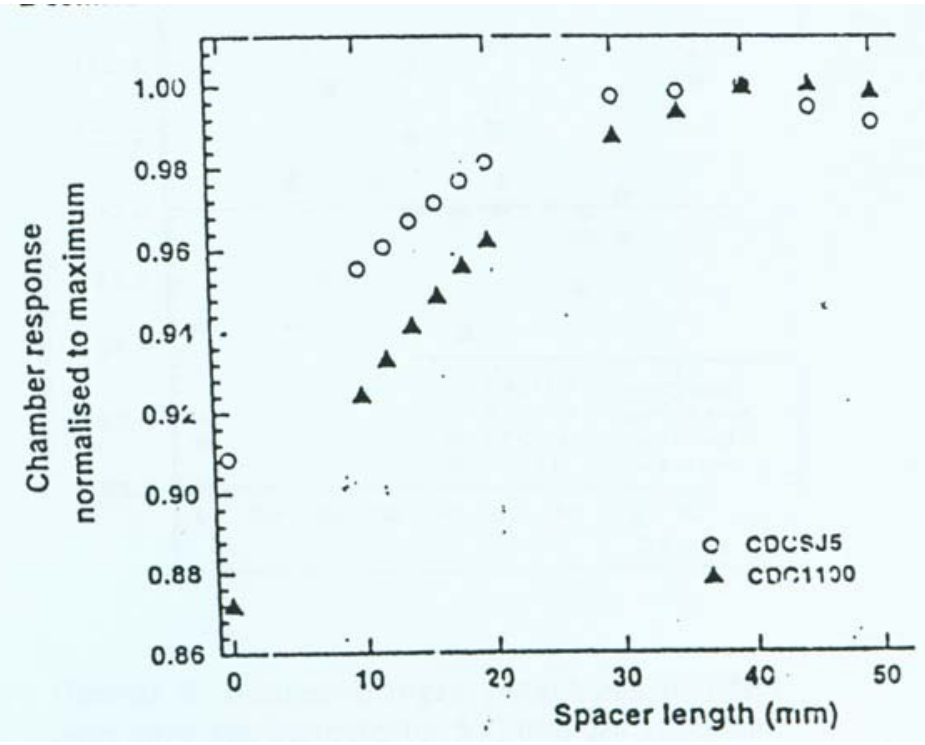

Gambar 3 Variasi Tanggapan Kamar Pengion Tipe Sumur terhadap Posisi Sumber dalam Kamar Pengion.

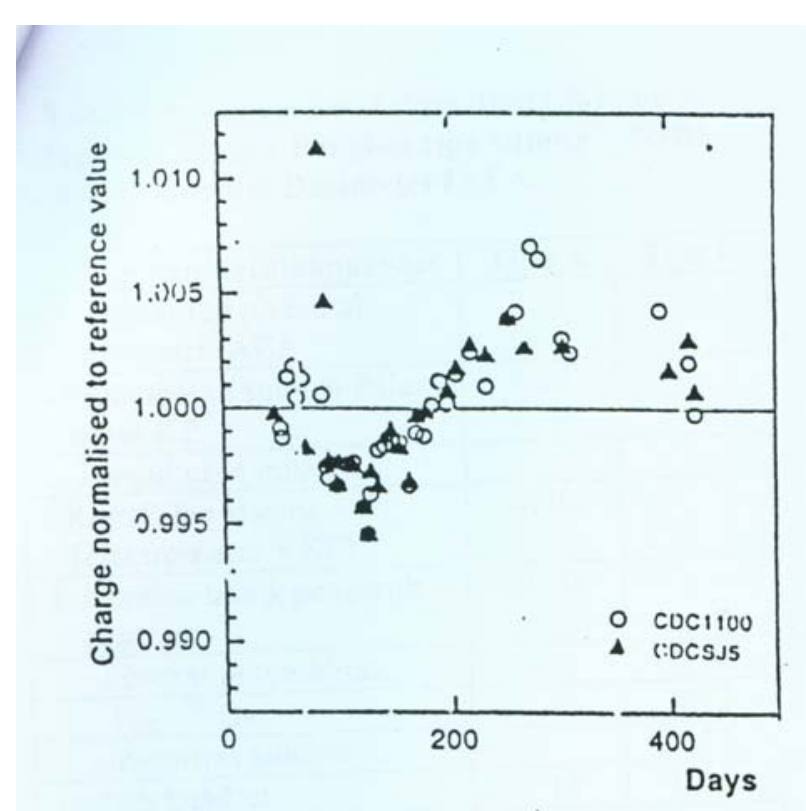

Gambar 4 Stabilitas Tanggapan Kamar Pengion Tipe Sumur.

Variasi tanggapan dinormalisir terhadap nilai acuan. Tanggapan umumnya dalam jangkauan $0,5 \%$.

Kamar pengion bola tipe LS-01 yang memiliki volume 1 liter digunakan pada jarak 500 $\mathrm{mm}, 750 \mathrm{~mm}$, dan $1000 \mathrm{~mm}$ dari sumber ke detektor. Geometri tersebut diilustrasikan pada Gambar 5. Sumber dalam holder perspex disisipkan pada batang logam, yang identik ukurannya dengan sumber. Elektrometer Keithley 617 digunakan untuk pengukuran tersebut dan arus bocor ditentukan kurang dari 70
$0,1 \%$ untuk sumber yang berkekuatan lebih rendah pada jarak paling besar. Stabilitas jangka pendek dan panjang dari alat ukur dan kedapatulangan geometri diperoleh dari pengukuran yang berulang. Tanggapan kamar pengion dikoreksi terhadap kondisi tekanan dan temperatur lingkungan dan terhadap peluruhan sumber. Stabilitas tanggapan kamar pengion, dinormalisir terhadap nilai rata-rata seluruh 
periode pengukuran, disajikan pada Gambar 6, yang dapat dilihat bahwa variasi umumnya dalam $\pm 0,5 \%$.

\subsection{Estimasi Ketidakpastian}

Ketidakpastian keseluruhan pada kalibrasi sumber acuan IAEA di NIST dinyatakan 2\% pada tingkat kepercayaan 95\%, mendekati $1 \%$ untuk $1 \sigma$. Tambahan ketidakpastian pengukuran di Laboratorium Dosimetri IAEA menghasilkan ketidakpastian kombinasi $<1,5 \%(1 \sigma)$. Rincian ketidakpastian disajikan pada Tabel 3.

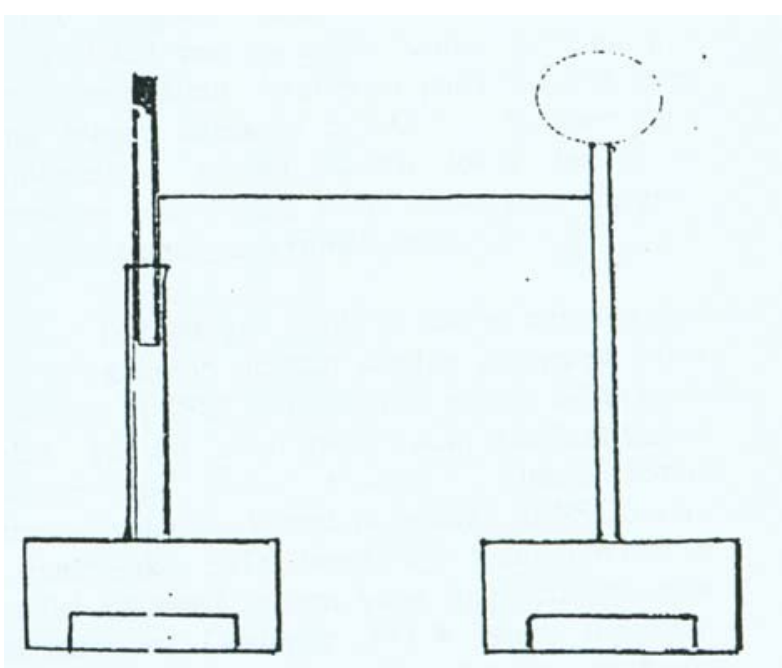

Gambar 5 Tampilan Pengukuran Sumber ${ }^{137} \mathrm{Cs}$ di Udara dengan Menggunakan Kamar Pengion LS-01 Berbentuk Bola dengan Volume 1 Liter

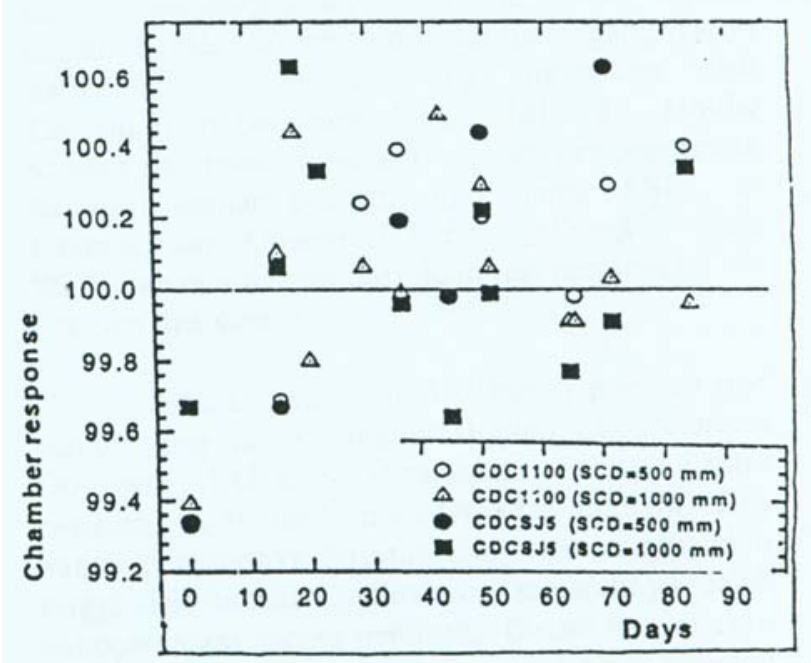

Gambar 6 Kedapatulangan Pengukuran di Udara pada Jarak Sumber Detektor 500 mm \& 1000 mm Tanggapan kamar pengion untuk setiap set pengukuran dinormalisir ke tanggapan rata-rata dari seluruh periode pengukuran. 
Tabel 3 Estimasi Ketidakpastian (\%) untuk Kalibrasi Kamar Pengion Tipe Sumur SSDL di laboratorium Dosimetri IAEA

\begin{tabular}{|l|r|r|}
\hline \multicolumn{1}{|c|}{ Komponen ketidakpastian } & \multicolumn{1}{|c|}{ Tipe A } & Tipe B \\
\hline $\begin{array}{l}\text { 1.Pengukuran pada Lab. } \\
\text { Dosimetri IAEA }\end{array}$ & 0,04 & \\
\hline $\begin{array}{l}\text { - Penempatan sumber dalam } \\
\text { sumur KP }\end{array}$ & & \\
\hline 2. Pengukuran muatan & 0,30 & \\
\hline $\begin{array}{l}\text { - Kestabilan sistem } \\
\text { (elektrometer + KP) }\end{array}$ & 0,20 & \\
\hline $\begin{array}{l}\text { 3. Koreksi untuk pengaruh } \\
\text { besaran: }\end{array}$ & & 0,10 \\
\hline - koreksi rekombinasi & & 0,12 \\
\hline - T $_{1 / 2}:{ }^{137}$ Cs & & 0,57 \\
\hline - impuritas sumber & 0,13 & 0,35 \\
\hline Jumlah kuadrat & 0,69 & \\
\hline Ketidakpastian gabungan, tipe A+B & 1,00 & \\
\hline Kalibrasi sumber acuan IAEA di NIST (A+B) & 1,21 & \\
\hline Ketidakpastian total A+B (1 deviasi standar) & & \\
\hline
\end{tabular}

\section{Catatan:}

Ketidakpastian untuk posisi sumber dan kestabilan ditentukan dari sederet pengukuran yang dilaksanakan di Lab. Dosimetri IAEA

Ketidakpastian untuk koreksi pengaruh besaran diambil dari acuan [8]

Ketidakpastian $\mathrm{T}_{1 / 2}$ diambil dari bagian data nuklir IAEA

Ketidakpastian akibat impuritas diambil dari keberadaan maksimum ${ }^{134} \mathrm{Cs}$ yang dinyatakan supplier.

\subsection{Prosedur di SSDL}

Prinsip umum bagan kalibrasi dan ketentuan teknis yang tertelusur diambil oleh Laboratorium Dosimetri IAEA untuk pengembangan metode yang telah dibahas pada bagian 2.1. Bagian ini menyajikan rincian prosedur kalibrasi yang disarankan (metode dan peralatan) untuk diaplikasikan oleh SSDL. SSDL perlu menetapkan ketertelusuran untuk standar LDR ${ }^{137}$ Cs ke PSDL lewat Laboratorium Dosimetri IAEA sehingga dapat meneruskan rantai ketertelusurannya ke rumah-sakit lokal.

Langkah-langkah transfer (pemindahan) kalibrasi dari sumber acuan IAEA ke sumber SSDL dapat diringkas sebagai berikut:

- Di Laboratorium Dosimetri IAEA, Faktor Kalibrasi untuk kamar pengion tipe sumur SSDL (Laju kerma acuan/bacaan skala) diperoleh menggunakan sumber acuan IAEA ${ }^{137} \mathrm{Cs}$.

- SSDL mengukur laju kerma udara acuan dari sumber lokal menggunakan kamar pengion tipe sumur yang telah dikalibrasi pada kondisi yang sama dengan kalibrasi di IAEA. Sumber yang dikalibrasi adalah standar lokal dan boleh digunakan oleh SSDL untuk melengkapi layanan kalibrasi ke pengguna rumah sakit.

Jika dengan kalibrasi kamar pengion tipe lain, pengukuran dengan sumber pengecek harus dilakukan di SSDL sebelum dan setelah kalibrasi di IAEA. Hal ini untuk pengecekan stabilitas kamar pengion tipe sumur tersebut. Untuk semua kalibrasi yang dilaksanakan, apakah di SSDL atau di rumah-sakit, SSDL harus dapat menjamin bahwa kondisi kalibrasi seperti yang diaplikasikan oleh Laboratorium Dosimetri IAEA harus dipenuhi. Singkatnya, bahwa semua pengukuran harus dilaksanakan di dalam suatu lingkungan yang hamburannya kecil. Jarak kamar pengion dengan dinding atau lantai sekurang-kurangnya $1 \mathrm{~m}$. Waktu minimum yang diperlukan sekitar 30 menit.

\subsubsection{Bahan}

Untuk mencapai ketertelusuran kalibrasi dengan ketidakpastian minimum, maka sumber acuan, holder sumber dan alat pemegangnyanya harus identik dengan yang digunakan oleh Laboratorium Dosimetri IAEA (Tabel 2). Holder sumber dan ruang (spacer) kamar pengion untuk 
kalibrasi kamar pengion tipe sumur SSDL di Laboratorium Dosimetri IAEA dilengkapi oleh SSDL sebagai bagian dari kalibrasi pertama kamar pengion tipe sumur.

SSDL harus memiliki kamar pengion tipe sumur yang harus dikalibrasi oleh Laboratorium Dosimetri IAEA. Disarankan bahwa kamar pengion tipe sumur terbuka terhadap atmosfer. Jika kamar pengionnya tertutup dan tekanan gas lebih tinggi dari tekanan sekitarnya, masalahnya dalah kebocoran gas secara perlahan. Dalam hal ini akan terjadi perubahan faktor kalibrasi. Kamar pengion yang terbuka perlu dikoreksi terhadap tekanan dan tempertatur, bila faktor kalibrasi didasarkan pada densitas udara pada $20{ }^{\circ} \mathrm{C}$ dan $101,3 \mathrm{kPa}$.

Harus dicatat bahwa kamar pengion tipe sumur dan elektrometer memiliki faktor kalibrasi yang independen. Faktor kalibrasi tersebut harus dikalikan bersama untuk membentuk faktor kalibrasi total dari sistem kamar pengion tipe sumur dan elektrometer tersebut. Jika tidak, maka faktor kalibrasi untuk seluruh sistem harus dilengkapi oleh Laboratorium Dosimetri IAEA. Faktor kalibrasi elektrometer harus ditentukan secara terpisah oleh SSDL, sebagai contoh dengan komparasi menggunakan elektrometer lain menggunakan sumber arus konstan.

\subsubsection{Metode}

\subsubsection{Kalibrasi Sumber Acuan SSDL}

Jika KP tipe sumur berbeda dengan yang digunakan Laboratorium Dosimetri IAEA, kurva tanggapan tidak perlu sama seperti Gambar 3. Dan SSDL harus menentukan karakteristiknya. Lagi pula, koreksi rekombinasi untuk kamar pengion tersebut harus ditentukan juga.

SSDL harus mengkalibrasi sumber acuan ${ }^{137} \mathrm{Cs}$ nya menggunakan kamar pengion terkalibrasi. Sumber acuan tersebut dimasukkan dalam tube Perspex dan ditetapkan posisinya, dengan menggunakan batangan yang dilengkapi oleh Lab. Dosimetri IAEA. Kemudian sumber tersebut dikalibrasi dengan meletakkannya di dalam sumur detektor. Bacaan tersebut harus dikoreksi terhadap tekanan dan temperatur dan dikalikan terhadap Faktor Kalibrasi yang diberikan oleh Laboratorium Dosimetri IAEA, dan akan memberikan Laju kerma udara acuan untuk sumber acuan SSDL.

\subsubsection{Kalibrasi KP Tipe Sumur Milik Rumah Sakit}

Bila KP (kamar pengion) rumah sakit dikalibrasi di SSDL, dilaksanakan menggunakan sumber acuan SSDL. Pertama tama, kurva tanggapan untuk KP rumah sakit harus ditentukan. Kemudian sumber dimasukkan ke dalam KP pada titik tanggapan maksimum. Koreksi terhadap rekombinasi ion pada kamar pengion tersebut harus ditentukan dan diperhitungkan bila perlu. Jika jenis KP tersebut terbuka, bacaannya harus dikoreksi terhadap temperatur dan tekanan. Kemudian ditentukan Faktor Kalibrasinya dalam istilah Laju Kerma Udara Acuan persatuan arus. Arusnya diukur dengan meng-akumulasi muatan dalam waktu tertentu.

KP rumah-sakit harus dikalibrasi di SSDL. Tetapi jika kalibrasi KP oleh SSDL dilaksanakan di rumah sakit, KP tipe sumur milik SSDL atau sumber acuan harus dibawa ke rumah sakit. Untuk alasan keselamatan, transportasi sumber umumnya tidak direkomendasikan. Sesampainya di rumah sakit, semua pencegahan dan kondisi kalibrasi yang telah disebutkan di atas harus diamati. Sumber ${ }^{137} \mathrm{Cs}$ kemudian dikalibrasi menggunakan KP tipe sumur milik SSDL pada posisi yang sesuai. Sekali sumber rumah sakit dikalibrasi, KP rumah sakit dapat dikalibrasi dengan prosedur berikut. Sekali KP rumah sakit terkalibrasi, sumbersumber tipe standar yang mirip dapat dikalibrasi dengan pengukuran dalam KP ini.

\subsubsection{Kalibrasi Sumber-sumber Non Standar}

Kalibrasi setiap sumber non standar ${ }^{137}$ Cs milik rumah sakit, misalnya sumber-sumber yang tidak sama atau yang karakteristiknya tidak sama dengan sumber acuan yang direkomendasikan (Tabel 2), dapat dilaksanakan dengan menggunakan KP tipe sumur yang telah dikalibrasi. Kerja di Laboratorium Dosimetri IAEA telah menunjukkan bahwa perbedaan di dalam Faktor Kalibrasi KP tipe sumur untuk dua sumber yang disarankan kurang dari $1 \%$. Jika sumber ${ }^{137} \mathrm{Cs}$ non standar ditempatkan di KP yang telah dikalibrasi, diharapkan bahwa kemungkinan ketidakpastiannya 2-3\% di dalam kalibrasi sumber (untuk Laju Kerma Udara Acuan). Jika rumah sakit tidak memiliki $\mathrm{KP}$, kalibrasi dilaksanakan oleh SSDL menggunakan KPSSDL yang telah dikalibrasi.

Sebagai alternatif, sumber non standar milik rumah sakit dapat dikirim ke SSDL untuk 
pengukuran di udara. Menggunakan teknik pengukuran di udara, laju kerma udara acuan dari sumber non standar dapat ditentukan dari perbandingan bacaan dengan sumber acuan SSDL dan sumber yang dikalibrasi. Jarak sumber detektor harus cukup jauh sehingga sumber seolah-olah seperti titik. Kriteria praktis adalah bahwa jarak antara pusat KP dengan pusat sumber sekurang-kurangnya 10 kali panjang sumber, untuk menjamin bahwa error yang diakibatkan oleh pendekatan sumber titik kurang dari $0,1 \%$. Kondisi ini dapat dicapai bila jarak sumber detektor $1 \mathrm{~m}$.

\subsection{Estimasi Ketidakpastian}

SSDL harus menyiapkan tabel ketidakpastian untuk kalibrasi KP tipe sumurnya yang mirip dengan Tabel 3. Lagi pula jika pengukuran di udara dilaksanakan, tabel ketidakpastian yang lain harus disiapkan untuk pengukuran di udara.

\subsection{Ketertelusuran dari Rumah Sakit ke PSDL}

Untuk setiap kalibrasi, pertama-tama yang harus dilakukan adalah memeriksa kondisi alat. KP milik rumah sakit atau SSDL harus diuji kestabilannya sebelum digunakan. Hal ini untuk memverifikasi apakah alat tersebut stabil setelah melakukan perjalanan. Ketertelusuran Laju Kerma Udara Acuan untuk sumber rumah sakit adalah melalui SSDL dan Laboratorium Dosimetri IAEA ke PSDL

\section{KONTROL KUALITAS}

\subsection{Aspek Keselamatan dalam Penggunaan Sumber Brakhiterapi}

Dosis yang diberikan ke pasien yang sedang menjalani perlakuan brakhiterapi sebanding dengan kekuatan sumbernya. Kekuatan sumber biasanya dicantumkan dalam sertifikat yang diberikan oleh pabrik pembuatnya. Berdasarkan pada protokol QC (Quality Control), disarankan tidak menggunakan nilai tersebut sebagai input perhitungan dosis, tanpa adanya verifikasi oleh ahli fisika medis yang terkualifikasi.

Sejumlah kecelakaan pada pasien di dalam perlakuan brakhiterapi LDR dan HDR $[9,10]$ yang dilaporkan adalah akibat dari dosis yang tidak terkoreksi. Tipe kecelakaan dan frekuensinya disajikan pada Tabel 4.

Kesalahan di dalam spesifikasi aktivitas sumber, perhitungan dosis atau besar dan satuan yang dihasilkan dalam dosis ternyata berada pada range $20-170 \%$ dari dosis yang tertera. Beberapa kesalahan diakibatkan oleh manusia sebagi contoh: sumber yang tidak benar digunakan untuk perlakuan karena kode sumber sudah memudar. Kecelakaan yang paling mengerikan disebabkan oleh kegagalan alat, dimana dosis lethal diberikan ke pasien.

Tabel 4 Tipe dan Frekuensi Kecelakaan dalam Brakhiterapi

\begin{tabular}{|l|r|}
\hline \multicolumn{1}{|c|}{ Penyebab kecelakaan } & Jumlah kasus \\
\hline Kesalahan perhitungan dosis & 6 \\
\hline Kesalahan besaran dan satuan & 2 \\
\hline Kekuatan sumber & 7 \\
\hline Kegagalan peralatan & 4 \\
\hline Lain-lain & 13 \\
\hline
\end{tabular}

Besaran yang disarankan oleh ICRU untuk spesifikasi sumber brakhiterapi adalah Laju Kerma Udara Acuan. Jika konversi harus dilakukan, harus digunakan faktor konversi.

\subsection{Karakteristik Kamar Pengion Tipe Sumur}

Metode yang dapat dipercaya untuk mengkalibrasi sumber brakhiterpi diantaranya adalah kamar pengion tipe sumur. Ada 2 tipe kamar pengion yang biasa digunakan di rumah- rumah sakit, yaitu kamar pengion bertekanan tinggi yang berisi gas argon. Respon kamar pengion tersebut harus di check secara regular menggunakan sumber yang berwaktu paro panjang. ${ }^{137} \mathrm{Cs}$ atau ${ }^{226} \mathrm{Ra}$ dapat digunakan untuk tujuan ini meskipun sumber lain juga dapat digunakan bila ada.

\subsection{Penyimpanan dan Penanganan Sumber LDR}

Wadah penyimpanan sumber biasanya disediakan oleh penjualnya tetapi dapat juga 
menggunakan wadah lokal, yang penting aman. Laju Dosis Ekivalen pada permukaan wadahnya tidak boleh lebih dari 20 mikro Sv/jam.

\subsection{Keselamatan Radiasi}

\subsubsection{Uji Kebocoran sumber acuan ${ }^{137} \mathrm{Cs}$}

Kebocoran sumber acuan harus diuji dengan uji usap basah (menggunakan tissue) setiap kali sumber acuan baru diterima dan untuk setiap penggantian tube ke dalam perspeks, dengan menggunakan catut panjang agar paparan terhadap operator dapat diminimalkan. Selanjutnya tissue tersebut diukur dengan monitor kontaminasi atau system pencacah spektrometri gamma.

\subsubsection{Pencegahan Lainnya}

Akibat sering digunakan mungkin saja prerspeks pecah/ retak, karena itu perlu diganti setiap 6 bulan atau paling tidak setahun sekali.

Sumber-sumber harus ditandai agar mudah diidentifikasi. Harus tersedia monitor radiasi di dekat sumber atau wadah sumber.

\subsection{Menjaga Ketertelusuran}

Untuk memonitor secara regular ketertelusuran dari kalibrasi brakhiterapi ke SSDL, disarankan rekalibrasi kamar pengion tipe sumur SSDL setiap lima tahun atau jika uji kestabilan kamar pengion mengalami perubahan.

\section{DAFTAR PUSTAKA}

1. Susworo, Peran Radioterapi pada pengobatan kanker, Kompas, 6 Januari 2002.

2. C.Deehan and Jao Donoghue, Biological Equivalence of LDR and HDR Brakhiterapy from Radium to Optimization, Nucletron International BV, 1994.

3. Kutcher, G.J. Coia., Gillin, M., Hanson, W.F., Leibel, S., Morton, Rj Palta, J.A. Purdy,L., Reinstein,E., Svenson, G.K., Weller,M., and Wingfield,L., Comprehensive QA for radiation oncology;
Report of AAPM Radiation Therapy Committee Task Group 40, Med.Phys.21 4 (1988), 581-618.

4. International Commision On Radiation Units and Measure-Ments, Dose and Volume Specification for Reporting Intracavitary Therapy in Gynaecology, ICRU Report 38, ICRU Publications, Bethesda, MD (1985).

5. International Commision On Radiation Units And Measurements, Dose and Volume Specification for Reporting Interstitial Therapy, ICRU Report 58, Washington DC (1997).

6. Weaver, J.T., Loftus, T.P., Loevinger, R., Calibration of Gamma Ray Emitting Brakhiterapy sources, NBS Special Publication 250-19, NBS (1988).

7. Dewerd, L.A., Thomadsen, B.R., Source Strenght standards and calibration of HDR/PDR sources, Brakhiterapy Physics: AAPM Summer School, (1994), 541.

8. Kondo, S., Randolph, M.L., Effect of finite size of ionization chambers on measurement of small photon sources, Rad.Res. 13 (1960), 37-60.

9. International Atomic Energy Agency, Lessons learned from accidental exposures in radiotherapy safety report series, IAEA, Vienna, To be published.

10. International Commision On Radiation Protection, Accidental prevention in radiation therapy, To be published.

11. Iaea-Tecdoc, Calibration of brachiterapy sources, Guidelines on Standardizaed Procedures for the Calibration of Brachiterapy Sources at SSDL and Hospitals, (1999).

\section{BIODATA}

Nazaroh, Dra, lahir di Pekalongan tanggal 10 Oktober 1961. Penulis menyelesaikan S1 FMIPA Universitas Indonesia jurusan Fisika Proteksi Radiasi. Penulis adalah Peneliti Madya LIPI. Saat ini bekerja sebagai Kasubid Standardisasi P3KRBin Batan. 


\title{
KAJIAN PENGEMBANGAN STANDAR NASIONAL INDONESIA (SNI) BIDANG AGROBASED DALAM RANGKA ASEAN ECONOMIC INTEGRATION
}

\author{
Muti Sophira Hilman dan Ellia Kristiningrum
}

\begin{abstract}
Abstrak
Indonesia adalah negara agraris yang memiliki sumber daya alam pertanian, perkebunan, kelautan yang sangat memadai, dan Indonesia mempunyai nilai ekspor terbesar untuk produk agro based. Integrasi Ekonomi ASEAN telah menetapkan 11 sektor prioritas ASEAN yang perlu diintegrasikan, salah satunya adalah sektor agro-based product. Perkembangan ASEAN integration saat ini telah mengharuskan setiap negara ASEAN untuk menentukan program-program prioritas produk yang perlu diharmonisasikan standarnya, termasuk standar untuk produk agro-based. Kajian ini menganalisa tentang keberadaan SNI produk agro-based yang harus dirumuskan atau di kaji ulang dalam rangka pengembangan standar produk agro-based. Dari kajian ini dapat disimpulkan bahwa prioritas pengembangan SNI untuk produk agro-based dapat ditentukan berdasarkan pada nilai terbesar dari nilai ekspor dan impor, selain itu juga berdasarkan value chain produk agro-based dan kesepakatan harmonisasi standar agro-based di ASEAN, dimana perkembangan SNI produk agro based tidak hanya standar produk tetapi juga standar mengenai food safety, food higiene, dan labelling.
\end{abstract}

Key word: SNI, Agro based, Integrasi ekonomi, ASEAN, Harmonisasi

\section{Abstract}

Indonesia is an agricultural country which has abundant resources of agriculture, livestock and marine and the biggest exporter for agro based product. ASEAN Economic Integration has specified 11 sectors of priority of ASEAN which require to be integrated, one of them is agro-based product sector. In this time, ASEAN integration has obliged each member of ASEAN to determine programs of priority of product standard which need to be harmonized, including standard of agro-based product. This study is analyzed about of SNI agro-based product which should be developed and review in order to develop of agro-based product standard. Result of this study is that priority of development of SNI product of agro-based determined base on biggest value of export and import, and then it is also based on value chain of agro-based product and agreement of harmonization of agro based standard in ASEAN, the development of SNI agrobased product not only standard of product but also standard of food safety, food hygiene, and labeling

Key Word: SNI, Agro-based, Economic Integration, ASEAN, Harmonization

\section{Pendahuluan}

ASEAN Economic Integration (AEI) merupakan suatu kesepakatan negara-negara ASEAN yang bertujuan untuk menjadikan kawasan ASEAN sebagai pasar tunggal dan pusat produksi yang ditandai dengan bebasnya arus barang, jasa, investasi, tenaga kerja maupun modal pada tahun 2020 nanti. Dalam rangka AEI ini, ditetapkan 11 sektor prioritas ASEAN yang perlu diintegrasikan, salah satunya adalah sektor agrobased product.

Langkah penting dalam kerangka kerja kesepakatan integrasi sektor prioritas tersebut (Framework Agreement for The Integration of Priority Sectors) salah satunya yaitu mempercepat perintisan perjanjian saling pengakuan (MRAs) dan mengharmonisasikan standar produk serta regulasi teknis.

Perkembangan kerjasama ASEAN Integration saat ini antara lain di setiap negara sudah harus menentukan program-program 76 prioritas produk yang perlu diharmonisasikan standarnya. Dalam realisasi kerjasama tersebut, perlu diketahui jenis-jenis standar produk yang perlu diharmonisasikan terutama standar mengenai produk agrobased.

Seperti diketahui, Indonesia adalah negara agraris yang memiliki sumber daya alam pertanian, perikanan, kelautan, perkebunan dan hutan yang memadai. Sebagian besar masyarakat memiliki mata pencaharian sebagai petani. Menurut data BPS(3), pada tahun 2002, dari 91,6 juta penduduk Indonesia yang bekerja, sekitar 44,34\% bekerja di sektor pertanian. Selama kurun waktu krisis ekonomi, sektor industri pertanian dan perkebunan mampu bertahan dan menunjukkan bahwa basis perekonomian bangsa adalah sesuai dengan kondisi geografis yaitu sebagai negara agraris. Potensi alam yang ada harus dapat dikembangkan untuk memenuhi kebutuhan dalam negeri yang sangat besar dan juga untuk tujuan ekspor. 
Dalam komoditi ekspor industri pertanian, perkebunan merupakan komoditi primer setelah sektor pertambangan. Besarnya nilai ekspor rata-rata pertahun selama lima tahun terakhir hampir 14,2 milyar USD hal ini menunjukkan bahwa sektor ini memberikan sumbangan devisa negara yang sangat berarti. Walaupun sempat mengalami penurunan pada tahun 2001, namun pada tahun-tahun berikutnya mengalami kenaikan rata-rata pertahun sebesar $3,78 \%$. Dengan rata-rata trend kenaikan sebesar ini mengindikasikan potensi pengembangan di masa yang akan datang sangat terbuka(6).

Beberapa negara tujuan utama ekspor Indonesia pada tahun 2003 untuk komoditi sektor ini cukup beragam. Ekspor komoditas kopi terbesar adalah ke negara Jepang dan Amerika Serikat yaitu berturut-turut sebesar 47,5 juta USD dan 40,8 juta USD. Ekspor teh hitam terbesar yaitu ke negara Inggris dan Myanmar sebesar 11,8 juta USD dan 6.1 juta USD. Ekspor lada putih terbesar yaitu ke negara Singapura sebesar 35 juta USD. Ekspor lada hitam terbesar ke negara Amerika Serikat dan Singapura, sebesar 15 juta USD dan 4,8 juta USD. Ekspor terbesar crude palm oil yaitu ke negara India dan
Belanda sebesar 154,6 juta USD dan 102,5 juta USD(3).

Dikarenakan ekspor agro-based yang cukup besar maka pengembangan Standar Nasional Indonesia (SNI) sektor ini perlu dikembangkan terutama dalam menghadapi ASEAN Economic Integration.

\section{Tujuan}

Mengetahui SNI produk agrobased yang perlu dirumuskan atau dikaji ulang untuk pengembangan standar bidang produk agrobased.

\section{Pembahasan}

\subsection{Struktur Agrobased Product}

Berdasarkan klasifikasi dari World custom Organization, agrobased product terdiri dari HS Chapter 06-14, 17-22 dan 24(5) .

\begin{tabular}{|c|c|c|c|}
\hline Chapter & Sector & \multirow{6}{*}{ Plants and Plant Products } & \\
\hline 06 & Live Trees & & \\
\hline 07 & Edible Vegetable & & \\
\hline 08 & Edible Fruits \& Nuts & & \\
\hline 09 & Coffee, Tea and Spices & & \multirow{13}{*}{ 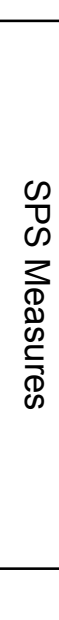 } \\
\hline 10 & Cereals & & \\
\hline 11 & Malt and Wheat Gluten & \multirow[b]{2}{*}{ ASEAN WG on Crops } & \\
\hline 12 & Seeds & & \\
\hline 13 & Lac, Gums \& Resins & & \\
\hline 14 & Other Vegetable Products & & \\
\hline 15 & Fats \& Oils & & \\
\hline 17 & Sugars & 5 & \\
\hline 18 & Cocoa & Foodstuff & \\
\hline 19 & Prep. Cereals/ Flour/ Milk & & \\
\hline 20 & $\begin{array}{lll}\text { Prep. Vegetables/ Fruit/ } \\
\text { Nuts }\end{array}$ & $\begin{array}{c}\text { ACCSQ Prepared } \\
\text { Foodstuff PWG }\end{array}$ & \\
\hline 21 & Misc. Edible Products & & \\
\hline 22 & Beverage & & \\
\hline 24 & Tobacco & & \\
\hline
\end{tabular}

Gambar 1 Struktur Agrobased Produk

Dari gambar 1 dapat dilihat bahwa kelompok Plant dan Plant product mencakup HS 06-14. Pengukuran sanitary and phytosanitary dan pengukuran lainnya berkenaan dengan standar dan conformity assessment untuk agricultural products/ commodities di ASEAN dilakukan oleh ASEAN Sectoral Working Groups on Crops dibawah Senior Official Meeting of the ASEAN Ministers on Agriculture and Forestry
(SOM AMAF). Kelompok foodstuff mencakup HS 15-24. Forum untuk kegiatan harmonisasi di ASEAN berkenaan dengan foodstuff proses yaitu ACCSQ Foodstuff Product Working Group (ACCSQ PFPWG), berkoordinasi dengan dua badan ASEAN yaitu ASEAN Taskforce on Codex for the harmonization of standards dan ASEAN Expert Groups on Food Safety (AEGFS) for food safety issues. 


\subsection{Ekspor dan Impor Produk Agrobased}

Nilai ekspor dan impor untuk produk agrobased ini dilihat berdasarkan nomor HS pada struktur agro-based, Indonesia mengekspor kurang lebih 474 produk agro-based dan mengimpor 483 jenis produk. Dari sekian banyak data nilai ekspor dan impor tersebut dipilih 50 besar nilai ekspor-impor.

Berdasarkan data ekspor-impor yang didapat dari Pusat Data Informasi Perdagangan Tahun 2004, nilai total ekspor terbesar yaitu 808.220.868 USD, untuk produk other palm oil, 656.760.657 USD untuk produk palm oil, dimana ekspor terbesar yaitu ke negara India dan Cina sebesar 173.470.815 USD dan 75.565.850 USD ( BPS tahun 2003), sedangkan ekspor terbesar ke negara ASEAN yaitu Singapura sebesar 19.637.856 USD. Daftar komoditi agrobased beserta nilai ekspor dapat dilihat pada Tabel 1 .

Nilai impor terbesar yaitu sebesar 404.090.931 USD untuk produk wheat. Untuk produk buah-buahan segar, Indonesia mengimpor cukup besar buah-buah seperti apel, jeruk, pear dan anggur. Sedangkan Indonesia mengekspor produk buah yaitu Pineapples in syrup dengan nilai ekspor yang besar yaitu 26.931.324 USD. Ekspor terbesar untuk jenis produk sayur-sayuran dan rempah-rempah, yaitu lada hitam senilai 10.470.337 USD. Disamping itu, Indonesia mengimpor cukup besar bawang putih, dimana impor terbesar tersebut berasal dari negara Cina. Untuk kelompok kacangkacangan Indonesia mengekspor cukup besar kacang pinang (areca nut shelled), nutmeg shelled dan kacang mete (cashew nut). Data lengkap untuk nilai ekspor dan impor ini dapat dilihat pada Tabel 2.

Besarnya nilai ekspor suatu produk dapat menunjukkan perkembangan industri dalam negeri yang baik, hal ini mendorong pemerintah untuk senantiasa meningkatkan produktivitas industri. Usaha tersebut dapat dilakukan dengan meningkatkan dan menjaga mutu produk melalui SNI produk.

Tabel 1 menunjukkan bahwa dari 50 produk yang terpilih, baru 30 produk yang mempunyai SNI dan 23 dari SNI tersebut sudah berumur lebih dari 5 tahun, sehingga perlu dilakukan kaji ulang. Diketahui bahwa dari 50 besar produk agrobased tersebut, sepuluh diantaranya mempunyai nilai ekspor besar yaitu lebih dari 35 juta USD. Produk yang mempunyai nilai ekspor besar ini dapat menjadi prioritas utama dalam pengembangan SNInya.

Produk Palm oil mempunyai nilai ekspor yang tertinggi, sedangkan SNI yang terkait yaitu SNI 01-0016-1998 mengenai crude palm olein ternyata berumur lebih dari 5 tahun sehingga perlu dilakukan kaji ulang. Begitu pula untuk produk lainnya yang SNInya telah berumur lebih dari 5 tahun, antara lain, crude oil of palm kernel, kopi robusta, cocoa butter fat and oil, cigarrette, dan palm kernel oil. Sedangkan crude oil of copra belum ada SNInya. Kaji ulang dilakukan apakah spesifikasi dan metode dalam standar tersebut perlu diperbaharui sesuai dengan perkembangan kebutuhan pasar dan teknologi terkini.

Selanjutnya pengembangan $\mathrm{SNI}$ untuk nilai ekspor yang cukup besar yaitu 10-34 juta USD seperti produk Pineapples in syrup and in airtight containers, black tea, vegetable fats \& oil $>=10 \mathrm{~kg}$, cocoa powder, coffee arabica, areca nuts shelled, tobacco, sweet biscuits, cloves, black pepper, crushed or ground, tabacco dan white pepper, crushed or ground

Nilai impor suatu produk yang besar mengindikasikan besarnya kebutuhan masyarakat akan produk tersebut. Dalam rangka melindungi konsumen, maka perlu dibuat SNI untuk produk tersebut dan apabila berkaitan dengan keamanan, keselamatan dan kesehatan maka SNI tersebut dapat diberlakukan wajib.

Tabel 2 menunjukkan 50 produk impor hanya 18 produk yang mempunyai SNI dan SNI yang sudah berumur lebih dari 5 tahun sebanyak 12 SNI produk. SNI yang lebih dari 5 tahun tersebut perlu dilakukan kaji ulang.

Produk yang mempunyai nilai impor besar yaitu lebih dari 35 juta USD dapat menjadi prioritas pengembangan SNInya. Produk yang mempunyai nilai impor paling tinggi yaitu gandum (wheat) dan jenis sereal lainnya, hal ini menunjukkan banyaknya konsumsi masyarakat Indonesia untuk produk gandum adalah tinggi, oleh karena ini untuk melindungi konsumen, perlu dipertimbangkan untuk merumuskan SNI mengenai gandum dan jenis sereal lainnya. Selain itu produk-produk lainnya yaitu other soya beans whether or not broken, other raw sugar refined white for pharmaceutical industry, maize ( corn ) other seeds, cane sugar, dan wheat or meslin flour. 
Tabel 1 Nilai Ekspor Produk Agrobased

\begin{tabular}{|c|c|c|c|c|c|}
\hline NO & HS & URAIAN & $\begin{array}{c}\text { NILAI } \\
\text { EKSPOR USD }\end{array}$ & NOMOR SNI & JUDUL SNI \\
\hline 1 & 151190000 & other palm oil & 808220868 & - & - \\
\hline 2 & 151110000 & crude palm oil & 656760657 & SNI 01-0016-1998 & $\begin{array}{l}\text { crude palm } \\
\text { olein }\end{array}$ \\
\hline 3 & 180100000 & $\begin{array}{l}\text { cocoa beans, whole or } \\
\text { broken, rawor roasted }\end{array}$ & 178319915 & SNI 01-2323-2002 & biji kakao \\
\hline 4 & 151321000 & $\begin{array}{l}\text { crude oil of palm } \\
\text { kernel }\end{array}$ & 159840475 & SNI 01-0003-1997 & $\begin{array}{l}\text { minyak inti } \\
\text { kelapa sawit }\end{array}$ \\
\hline 5 & 090111300 & $\begin{array}{l}\text { coffee,not roasted not } \\
\text { decaffeinaterobusta } \\
\text { oib }\end{array}$ & 73486163 & SNI 01-2907-1999 & biji kopi \\
\hline 6 & 151311000 & crude oil of copra & 67796026 & & \\
\hline 7 & 180400000 & $\begin{array}{l}\text { cocoa butter, fat and } \\
\text { oil. }\end{array}$ & 46925869 & SNI 01-3748-1995 & lemak kakao \\
\hline 8 & 240220900 & other cigarettes & 45613166 & SNI 01-0765-1999 & rokok putih \\
\hline 9 & 151790910 & $\begin{array}{l}\text { other edible mixture of } \\
\text { vegetableorigin }\end{array}$ & 37527500 & - & - \\
\hline 10 & 151329000 & other palm kernel oil & 35128041 & SNI 01-0024-1987 & $\begin{array}{l}\text { crude palm } \\
\text { kernel fatty } \\
\text { acid }\end{array}$ \\
\hline 11 & 200820300 & $\begin{array}{l}\text { pineapples in syrup } \\
\text { and in airtight } \\
\text { containers }\end{array}$ & 26931324 & SNI 01-3166-1992 & nenas \\
\hline 12 & 090240200 & $\begin{array}{l}\text { other black tea } \\
\text { (fermeted) dust }\end{array}$ & 26750023 & - & - \\
\hline 13 & 151620100 & $\begin{array}{l}\text { vegetable fats \& oil >= } \\
10 \mathrm{~kg}\end{array}$ & 24116328 & - & - \\
\hline 14 & 180500000 & $\begin{array}{l}\text { cocoa powder, not } \\
\text { containing addedsugar } \\
\text { / other sweetening } \\
\text { matter }\end{array}$ & 22251258 & SNI 01-3747-1995 & kakao bubuk \\
\hline 15 & 090111200 & $\begin{array}{l}\text { coffee,not roasted not } \\
\text { decaffeinatearabica } \\
\text { wib }\end{array}$ & 21820095 & SNI 01-2907-1999 & biji kopi \\
\hline 16 & 080290120 & areca nuts shelled & 21298955 & - & - \\
\hline 17 & 151319000 & other copra oil & 20497496 & - & - \\
\hline 18 & 240110900 & $\begin{array}{l}\text { tobacco, not } \\
\text { stemmed/stripped of } \\
\text { other than virginia }\end{array}$ & 19938243 & SNI 01-0612-1989 & $\begin{array}{l}\text { tembakau } \\
\text { shag }\end{array}$ \\
\hline 19 & 170490120 & not medicated sweets & 19901582 & - & - \\
\hline 20 & 151710900 & $\begin{array}{l}\text { margarine, excl. liquid } \\
\text { margarinein other } \\
\text { container }\end{array}$ & 19360163 & SNI 01-3541-2002 & \\
\hline 21 & 090230000 & $\begin{array}{l}\text { black tea (fermented) } \\
\text { and partlyfermented }\end{array}$ & 18453663 & SNI 01-1902-1995 & teh hitam \\
\hline 22 & 190530100 & sweet biscuits & 15273916 & SNI 01-2973-1992 & biscuit \\
\hline 23 & 090700100 & cloves & 11925184 & SNI 01-3392-1994 & $\begin{array}{l}\text { cengkeh } \\
\text { bukan untuk } \\
\text { obat }\end{array}$ \\
\hline 24 & 190219900 & $\begin{array}{l}\text { other paste not } \\
\text { containing eggs }\end{array}$ & 11919789 & - & - \\
\hline
\end{tabular}




\begin{tabular}{|c|c|c|c|c|c|}
\hline NO & HS & URAIAN & $\begin{array}{c}\text { NILAI } \\
\text { EKSPOR USD }\end{array}$ & NOMOR SNI & JUDUL SNI \\
\hline 25 & 090411390 & $\begin{array}{l}\text { black pepper, crushed } \\
\text { or ground }\end{array}$ & 10470337 & $\begin{array}{l}\text { SNI 01-0005-1995; } \\
\text { SNI 01-3716-1995 }\end{array}$ & $\begin{array}{l}\text { lada hitam; } \\
\text { lada hitam } \\
\text { bubuk }\end{array}$ \\
\hline 26 & 240120900 & $\begin{array}{l}\text { tabacco, partly or } \\
\text { wholly } \\
\text { stemmed/stripped of } \\
\text { other than virginia }\end{array}$ & 10402731 & $\begin{array}{l}\text { SNI 01-3934 s.d. } \\
\text { 3944-1995; SNI 01- } \\
4101 \text { 01-4102- } \\
\text { 1996; SNI 4402- } \\
\text { 1996; SNI 01-6238, } \\
\text { SNI 01-6239-2000 }\end{array}$ & $\begin{array}{l}\text { tembakau } \\
\text { rajangan }\end{array}$ \\
\hline 27 & 090411290 & $\begin{array}{l}\text { white pepper, crushed } \\
\text { or ground }\end{array}$ & 10334872 & $\begin{array}{l}\text { SNI 01-0004-1995; } \\
\text { SNI 01-3717-1995 }\end{array}$ & $\begin{array}{l}\text { lada } \\
\text { putih;lada } \\
\text { putih bubuk }\end{array}$ \\
\hline 28 & 090810200 & nutmeg shelled & 9967246 & - & - \\
\hline 29 & 140120100 & $\begin{array}{l}\text { rattan mixed, roughly } \\
\text { rubbed, unwashed, } \\
\text { smoked or sulphured }\end{array}$ & 9574967 & - & - \\
\hline 30 & 090610000 & $\begin{array}{l}\text { cinnamon \& } \\
\text { cinnamon-tree } \\
\text { flowersneither crushed } \\
\text { nor ground }\end{array}$ & 9275005 & SNI 01-3714-1995 & $\begin{array}{l}\text { kayu manis } \\
\text { bubuk }\end{array}$ \\
\hline 31 & 080131000 & cashew nut in shell & 9237498 & SNI 01-4463-1998 & $\begin{array}{l}\text { mete } \\
\text { gelondong }\end{array}$ \\
\hline 32 & 090500100 & vanilla whole & 8230323 & SNI 01-0010-2002 & panili \\
\hline 33 & 121220100 & seaweeds & 7748265 & SNI 01-2690-1998 & $\begin{array}{l}\text { rumput laut } \\
\text { kering }\end{array}$ \\
\hline 34 & 200310100 & $\begin{array}{l}\text { mushrooms in airtight } \\
\text { containers }\end{array}$ & 7040300 & $\begin{array}{l}\text { SNI 01-2741-1992; } \\
\text { SNI 01-2742-1992 }\end{array}$ & $\begin{array}{l}\text { jamur } \\
\text { kancing } \\
\text { dalam kaleng } \\
\text { atau botol; } \\
\text { jamur } \\
\text { merang } \\
\text { dalam kaleng } \\
\text { atau botol }\end{array}$ \\
\hline 35 & 190230000 & other pasta & 7027483 & - & - \\
\hline 36 & 240120100 & $\begin{array}{l}\text { tabacco, partly or } \\
\text { wholly } \\
\text { stemmed/stripped } \\
\text { virginia type flue cured }\end{array}$ & 6759659 & $\begin{array}{l}\text { SNI 01-4401-1996, } \\
\text { SNI 01-4101-1996 }\end{array}$ & $\begin{array}{l}\text { tembakau } \\
\text { virginia } \\
\text { fc,tembakau } \\
\text { rajangan } \\
\text { virginia } \\
\text { bojonegoro } \\
\end{array}$ \\
\hline 37 & 200940990 & $\begin{array}{l}\text { pineapple juice not for } \\
\text { retail sale }\end{array}$ & 6701394 & - & - \\
\hline 38 & 080111000 & coconut desiccated & 6239457 & - & - \\
\hline 39 & 090500900 & other vanilla & 5119026 & SNI 01-0010-2002 & panili \\
\hline 40 & 210390900 & $\begin{array}{l}\text { other sauces \& } \\
\text { preparation there of }\end{array}$ & 5002965 & - & - \\
\hline 41 & 210111000 & $\begin{array}{l}\text { extracts, essences } \\
\text { and concentrates of } \\
\text { coffee }\end{array}$ & 4883166 & - & - \\
\hline 42 & 170490990 & $\begin{array}{l}\text { other confectionary } \\
\text { sugar }\end{array}$ & 4827500 & $\begin{array}{l}\text { SNI 01-3140-2001, } \\
\text { SNI 01-4086-1996 }\end{array}$ & $\begin{array}{l}\text { gula kristal } \\
\text { putih } \\
\text { (plantation } \\
\text { white } \\
\text { sugar),gula }\end{array}$ \\
\hline
\end{tabular}




\begin{tabular}{|c|c|c|c|c|c|}
\hline NO & HS & URAIAN & $\begin{array}{c}\text { NILAI } \\
\text { EKSPOR USD }\end{array}$ & NOMOR SNI & JUDUL SNI \\
\hline & & & & & $\begin{array}{l}\text { pasir } \\
\text { berstevia }\end{array}$ \\
\hline 43 & 180632000 & $\begin{array}{l}\text { oth chocolate in } \\
\text { blocks, slabs/barsnot } \\
\text { filled }\end{array}$ & 4522351 & - & - \\
\hline 44 & 152000000 & $\begin{array}{l}\text { glycerol, crude; } \\
\text { glycerol watersand } \\
\text { glycerol lyes }\end{array}$ & 4496120 & SNI 06-1564-1999 & gliserol kasar \\
\hline 45 & 110100000 & wheat or meslin flour. & 4159137 & SNI $01-3751-2000$ & \\
\hline 46 & 180320000 & $\begin{array}{l}\text { cocoa paste } \\
\text { wholly/partly defatted }\end{array}$ & 4038800 & SNI 01-4458-1998 & pasta cokelat \\
\hline 47 & 240210000 & $\begin{array}{l}\text { cigars, cheroots and } \\
\text { cigarillos, containing } \\
\text { tobacco }\end{array}$ & 3948696 & SNI 01-0766-1989 & rokok kretek \\
\hline 48 & 151000000 & $\begin{array}{l}\text { other oils and their } \\
\text { fractions,obtained } \\
\text { solely from olives }\end{array}$ & 3885880 & - & - \\
\hline 49 & 090111900 & $\begin{array}{l}\text { other coffee,not } \\
\text { roasted } \\
\text { notdecaffeinated }\end{array}$ & 3852188 & - & - \\
\hline 50 & 140410300 & gambir & 3841842 & - & - \\
\hline
\end{tabular}

Tabel 2 Nilai Impor Produk Agrobased

\begin{tabular}{|l|l|l|l|l|l|}
\hline No & \multicolumn{1}{|c|}{ HS } & \multicolumn{1}{|c|}{ URAIAN } & $\begin{array}{c}\text { NILAI } \\
\text { IMPOR USD }\end{array}$ & \multicolumn{1}{|c|}{ SNI TERKAIT } & JUDUL SNI \\
\hline 1 & 100190190 & $\begin{array}{l}\text { Wheat other than } \\
\text { seeds }\end{array}$ & 404090931 & - & - \\
\hline 2 & 120100900 & $\begin{array}{l}\text { Other soya beans } \\
\text { whether or not } \\
\text { broken }\end{array}$ & 228493828 & - & - \\
\hline 3 & 170199191 & $\begin{array}{l}\text { Other raw sugar } \\
\text { refined white for } \\
\text { pharmaceutical } \\
\text { industry }\end{array}$ & 82268735 & SNI 01- 3140.2-2001 & $\begin{array}{l}\text { Gula kristal } \\
\text { rafinasi }\end{array}$ \\
\hline 4 & 100590000 & $\begin{array}{l}\text { Maize ( corn ) other } \\
\text { seeds }\end{array}$ & 54144958 & SNI 01- 3727-1995 & $\begin{array}{l}\text { Tegung } \\
\text { Jagung }\end{array}$ \\
\hline 5 & 170111000 & $\begin{array}{l}\text { Cane sugar } \\
\text { Gunah } \\
\text { tebu }\end{array}$ \\
\hline 6 & 110100000 & $\begin{array}{l}\text { Wheat or meslin } \\
\text { flour. }\end{array}$ & 35264435 & SNI 01-3751-2000 & $\begin{array}{l}\text { Tepung } \\
\text { terigu }\end{array}$ \\
\hline 7 & 240120100 & $\begin{array}{l}\text { Tabacco, partly or } \\
\text { wholly } \\
\text { stemmed/stripped } \\
\text { virginia type flue } \\
\text { cured }\end{array}$ & 33815665 & $\begin{array}{l}\text { SNI 01-4401-1996, } \\
\text { SNI 01-4101-1996 }\end{array}$ & $\begin{array}{l}\text { Tembakau } \\
\text { Virginia } \\
\text { FC,Tembaka } \\
\text { u rajangan } \\
\text { virginia } \\
\text { Bojonegoro }\end{array}$ \\
\hline 8 & 080810000 & Apples fresh & 31155161 & - & SNI 01 - 6237-2000 \\
\hline 9 & 180100000 & Cocoa beans, whole & 31067841 & SNI 01-2323-2002 & - \\
\hline
\end{tabular}




\begin{tabular}{|c|c|c|c|c|c|}
\hline No & HS & URAIAN & $\begin{array}{c}\text { NILAI } \\
\text { IMPOR USD }\end{array}$ & SNI TERKAIT & JUDUL SNI \\
\hline & & $\begin{array}{l}\text { or broken, rawor } \\
\text { roasted }\end{array}$ & & & \\
\hline 10 & 100630000 & $\begin{array}{l}\text { Semi-milled or wholly } \\
\text { milled rice,whether or } \\
\text { not polished or } \\
\text { glazed }\end{array}$ & 27056509 & SNI 01-6128-1999 & Beras giling \\
\hline 11 & 210690900 & $\begin{array}{l}\text { Other food } \\
\text { preparation n.e.s }\end{array}$ & 24237574 & - & - \\
\hline 12 & 210690210 & $\begin{array}{l}\text { Non-alcoholic } \\
\text { preparations use } \\
\text { formaking beverages } \\
\text { in packing }>=25 \mathrm{~kg}\end{array}$ & 23778390 & - & - \\
\hline 13 & 240310100 & $\begin{array}{l}\text { Blended tobacco of } \\
\text { burley type }\end{array}$ & 22628549 & - & - \\
\hline 14 & 070320000 & Garlic fresh or chilled & 21443643 & SNI 01-3160-1992 & $\begin{array}{l}\text { Bawang } \\
\text { Putih }\end{array}$ \\
\hline 15 & 080520110 & Mandarins fresh & 19296992 & - & - \\
\hline 16 & 080820000 & $\begin{array}{l}\text { Pears and quinces } \\
\text { fresh }\end{array}$ & 14976535 & - & - \\
\hline 17 & 080510100 & Oranges fresh & 13700486 & SNI 01-3165-1992 & Jeruk keprok \\
\hline 18 & 170199900 & Other raw sugar & 13590790 & SNI 01-3140.1-2001 & $\begin{array}{l}\text { Gula kristal } \\
\text { mentah (raw } \\
\text { sugar) }\end{array}$ \\
\hline 19 & 070310200 & $\begin{array}{l}\text { Shallots fresh or } \\
\text { chilled }\end{array}$ & 12699756 & - & - \\
\hline 20 & 080610000 & Grapes fresh & 11696413 & - & - \\
\hline 21 & 190110000 & $\begin{array}{l}\text { Prep. Malt extract for } \\
\text { infant use,put up for } \\
\text { retail sale }\end{array}$ & 11046859 & - & - \\
\hline 22 & 170490120 & $\begin{array}{l}\text { Not medicated } \\
\text { sweets }\end{array}$ & 10548344 & 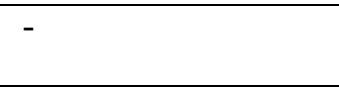 & 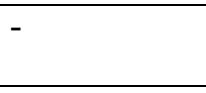 \\
\hline 23 & 120100100 & $\begin{array}{l}\text { Soya beans, whether } \\
\text { or not broken yellow }\end{array}$ & 9893595 & SNI 01-3922-1995 & Soya beans \\
\hline 24 & 120220000 & $\begin{array}{l}\text { Ground-nuts, not } \\
\text { roasted/otherwhiseco } \\
\text { oked shelled,whether } \\
\text { / not broken }\end{array}$ & 8568301 & - & - \\
\hline 25 & 152200000 & $\begin{array}{l}\text { Degras; residues } \\
\text { resulting from the } \\
\text { treatment fatty } \\
\text { subtances }\end{array}$ & 8509810 & - & - \\
\hline 26 & 240120900 & $\begin{array}{l}\text { Tabacco, partly or } \\
\text { wholly } \\
\text { stemmed/stripped of } \\
\text { other than virginia }\end{array}$ & 7958620 & $\begin{array}{l}\text { SNI 01-3934 s.d. } \\
\text { 3944-1995; SNI 01- } \\
\text { 4101 01-4102-1996; } \\
\text { SNI 4402-1996; SNI } \\
\text { 01-6238, SNI 01- } \\
6239-2000\end{array}$ & $\begin{array}{l}\text { Tembakau } \\
\text { rajangan }\end{array}$ \\
\hline 27 & 220290000 & $\begin{array}{l}\text { Other mineral water } \\
\text { containing added } \\
\text { sugar }\end{array}$ & 7654336 & - & - \\
\hline 28 & 110814000 & $\begin{array}{l}\text { Manioc (cassava) } \\
\text { starch }\end{array}$ & 6998309 & SNI 01-2997-1996 & $\begin{array}{l}\text { Tepung } \\
\text { singkong }\end{array}$ \\
\hline 29 & 210112000 & $\begin{array}{l}\text { Preparations with a } \\
\text { basis ofextracts, }\end{array}$ & 6830852 & - & - \\
\hline
\end{tabular}




\begin{tabular}{|c|c|c|c|c|c|}
\hline No & HS & URAIAN & $\begin{array}{c}\text { NILAI } \\
\text { IMPOR USD }\end{array}$ & SNI TERKAIT & JUDUL SNI \\
\hline & & basis of coffee & & & \\
\hline 30 & 100510000 & Maize ( corn ) seeds & 6467652 & $\begin{array}{l}\text { SNI 6232.1; 6232.2, } \\
6232.3,6232.4-2003\end{array}$ & Benih jaung \\
\hline 31 & 100640000 & Broken rice & 6446713 & - & - \\
\hline 32 & 081090190 & $\begin{array}{l}\text { Other tropical fruits } \\
\text { fresh }\end{array}$ & 5561693 & - & - \\
\hline 33 & 150790100 & $\begin{array}{l}\text { Neutralized and } \\
\text { bleached }\end{array}$ & 5281952 & - & - \\
\hline 34 & 071331000 & $\begin{array}{l}\text { Beans of the species } \\
\text { vigna mungohepper/ } \\
\text { vigna radiata wilczek } \\
\text { dried }\end{array}$ & 5264868 & - & - \\
\hline 35 & 240110100 & $\begin{array}{l}\text { Tobacco, not } \\
\text { stemmed/strippedvirg } \\
\text { inia type flue cured }\end{array}$ & 5129758 & - & - \\
\hline 36 & 081090120 & Durian fresh & 5034720 & SNI 01-4482-1998 & Durian \\
\hline 37 & 240110900 & $\begin{array}{l}\text { Tobacco, not } \\
\text { stemmed/strippedof } \\
\text { other than virginia }\end{array}$ & 4745961 & SNI 01-0612-1989 & $\begin{array}{l}\text { Tembakau } \\
\text { shag }\end{array}$ \\
\hline 38 & 210390900 & $\begin{array}{l}\text { Other sauces \& } \\
\text { preparation there of }\end{array}$ & 4452163 & - & - \\
\hline 39 & 190190910 & $\begin{array}{l}\text { Other malt extract in } \\
\text { pack. }>=25 \mathrm{~kg}\end{array}$ & 4419642 & - & - \\
\hline 40 & 200410000 & $\begin{array}{l}\text { Potatoes prepared or } \\
\text { preserved oth.wise } \\
\text { than by vihegar } \\
\text { frozen }\end{array}$ & 4366504 & - & - \\
\hline 41 & 110710100 & $\begin{array}{l}\text { Malt not roasted } \\
\text { unground }\end{array}$ & 4290999 & - & - \\
\hline 42 & 180500000 & $\begin{array}{l}\text { Cocoa powder, not } \\
\text { containing } \\
\text { addedsugar / other } \\
\text { sweetening matter }\end{array}$ & 3899005 & SNI 01-3747-1995 & Kakao bubuk \\
\hline 43 & 151620100 & $\begin{array}{l}\text { Vegetable fats \& oil } \\
>=10 \mathrm{~kg}\end{array}$ & 3599037 & SNI 01-3191-1992 & $\begin{array}{l}\text { Penentuan } \\
\text { warna } \\
\text { minyak } \\
\text { nabati } \\
\end{array}$ \\
\hline 44 & 180690000 & $\begin{array}{l}\text { Sugar confectionary } \\
\text { containing cocoa in } \\
\text { any proportion }\end{array}$ & 3576307 & - & - \\
\hline 45 & 180610000 & $\begin{array}{l}\text { Cocoa powder, } \\
\text { containing } \\
\text { addedsugar / other } \\
\text { sweetening matter }\end{array}$ & 3543705 & - & - \\
\hline 46 & 100620000 & Husked (brown) rice & 3311854 & - & - \\
\hline 47 & 170290900 & Other invert sugar & 3077114 & - & - \\
\hline 48 & 210610000 & $\begin{array}{l}\text { Protein concentrates } \\
\text { and textured protein } \\
\text { substances }\end{array}$ & 3052021 & - & - \\
\hline 49 & 210210000 & Active yeasts & 2982997 & - & - \\
\hline 50 & 180620000 & $\begin{array}{l}\text { Oth preparations } \\
\text { containing cocoa }\end{array}$ & 2812362 & - & - \\
\hline
\end{tabular}




\subsection{Value Chain untuk Produk Pangan dan Agroindustrial}

Gambar 2 di bawah ini menunjukkan rantai nilai untuk produk pangan dan agroindustrial. Gagasan dari rantai nilai adalah pergerakkan downstream (ke arah manufacturing, marketing, dan services), nilai tambahnya (value added) relatif lebih tinggi dibanding nilai tambah pada bagian upstream yaitu pada bagian pertanian dan pengolahan utama.

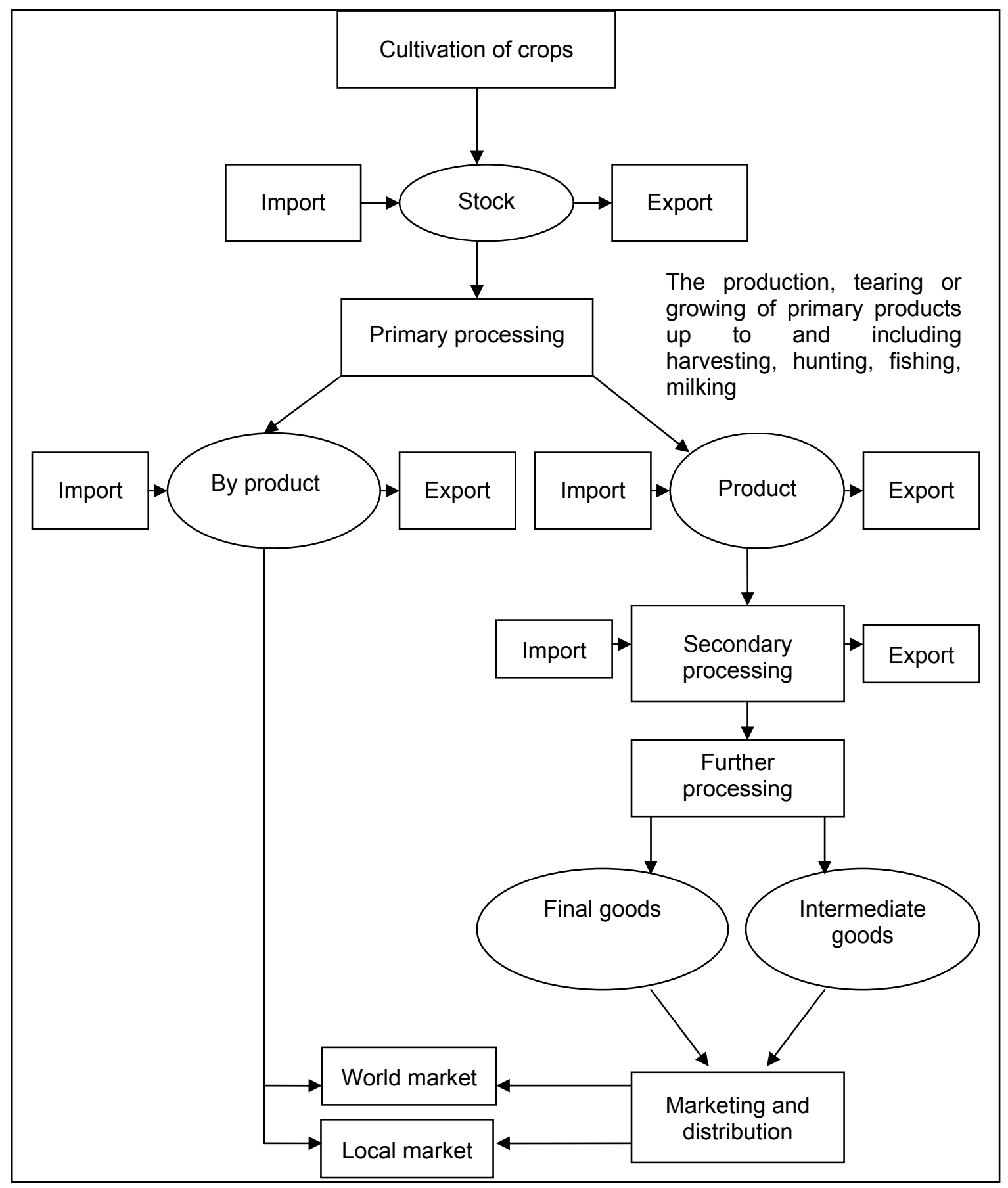

Gambar 2 Value Chain untuk Produk Pangan dan Agroindustrial

Proporsi pendapatan paling tinggi diperoleh dari aktifitas di bagian downstream, 84 semakin maju suatu negeri maka semakin sedikit ketergantungan kepada fluktuasi bahan pokok di 
pasaran. Begitu pula, dengan bergerak mengarah ke downstream dalam value chain ini, suatu negara dapat meningkatkan daya kompetitif di internasional market.

Pada bagian upstream ini menyangkut persediaan bahan baku (stock). Sedangkan pada bagian downstream meliputi kegiatan pengolahan lebih lanjut (futher processing), sistem distribusi, atau jasa makanan (food services operation). Sasaran utama integrasi upstream adalah mengamankan persediaan bahan baku. Integrasi upstream memungkinkan agroindustri untuk mengendalikan mutu bahan baku (raw materials). Kemudian isu berkembang berkaitan dengan keselamatan makanan dan produksi yang tersertifikasi (certified productions). Integrasi downstream meliputi perluasan aktivitas ke arah konsumen. Integrasi tersebut memberikan nilai tambah untuk produk dan/atau peningkatan kendali penjualan (sales control), selain itu juga meliputi perluasan ke dalam sektor jasa makanan (food service sector), industri makanan dan pertumbuhan distributor makanan, .

Melihat value chain dari produk agrobased tersebut, nilai ekspor Indonesia lebih banyak pada bagian downstream yaitu pada bagian intermediate dan final goods (lampiran), hal ini menunjukkan Indonesia sebenarnya dapat berkompetisi untuk bidang agro-based, salah satu caranya adalah dengan mengembangkan standar produk agro-based sehingga mutu produk agro-based meningkat dan dapat bersaing di pasar Internasional.

Dalam perdagangan produk agro-based ini, standar dan sertifikasi internasional sangat diperlukan, karena memudahkan perdagangan internasional, dan juga dapat meningkatkan daya saing. Standar dan sertifikasi mengenai aturan pemberian label, pembungkus (packaging), standar identitas, aturan pemeriksaan memerintah atau peraturan tentang asal produk juga menjadi perhatian industri makanan.

\subsection{Harmonisasi Standar Pangan Dalam Rangka AEI}

Standardisasi pangan di ASEAN dikoordinasikan melalui ASEAN Task Force on Codex (ATFC). Seperti diketahui bahwa standar makanan diharmonisasi ke standar internasional menjadi standar Codex, salah satu referensi yang dapat diterima oleh WTO dalam penerapan SPS Agreement.
Kegiatan harmonisasi juga dilakukan melalui workshop informal ASEAN Food Safety Standards Harmonization. Hasil dari workshop informal ini dapat dilihat sebagai dasar untuk mendukung kegiatan harmonisasi di ASEAN untuk area agro-based, fisheries dan sektor makanan. Workshop harmonisasi ini didukung oleh International Life Science Institute (ILSI) and $\mathrm{FAO}$.

Di ASEAN untuk komoditi buah-buahan, sayur-sayuran dan komoditi agriculture lainnya (HS 7-14) telah dilakukan harmonisasi mengenai prosedur quarantine, MRL untuk residu peptisida dan elaborasi pedoman untuk Guidelines on the Risk Assessment of Agriculture-related Genetically Modified Organisms (GMOs). Selain itu banyak hal yan perlu dilakukkan untuk mendorong daya kompetitif dari produk/komoditi di ASEAN, terutama mengenai quality and safety.

Untuk processed foodstuff (HS 15-23), pencapaian yang paling terkemuka di ASEAN adalah "ASEAN General Guidelines on the Preparation and Handling of Halal Food". Kepercayaan akan food safety untuk konsumsi manusia dan juga food hygiene pada seluruh tahap produksi mulai dari preparation, processing, manufacturing, packaging, storing, transportation, distribution, handling dan sale dan supply ke konsumen perlu dibangun antara negara pengimpor dan negara pengekspor. Di ASEAN untuk processed foodstuff, disepakati untuk adanya harmonisasi mengenai Requirements on Food Labelling, Import- Export, Certification and Registration Procedures.

\subsection{Kesimpulan}

Berdasarkan paparan diatas dapat ditentukan prioritas perumusan atau pengembangan SNI berdasarkan:

a. Nilai ekspor, besarnya nilai ekspor suatu produk dapat menunjukkan perkembangan industri dalam negeri yang baik, untuk meningkatkan produktivitas industri dapat dilakukan dengan meningkatkan dan menjaga mutu produk melalui SNI produk. Sepuluh produk yang mempunyai nilai ekspor terbesar dapat menjadi prioritas pengembangan SNI yaitu other palm oil, crude palm oil, cocoa beans, crude oil of palm kernel, coffee,not roasted not decaffeinate robusta, crude oil of copra, cocoa butter, fat and oil, other cigarettes, other edible mixture of vegetable origin, dan 
other palm kernel oil. (kecualli untuk cocoa bean SNI nya ditetapkan tahun 2002 sehingga dapat dilakukan review lima tahun mendatang).

b. Nilai Impor, besarnya nilai impor suatu produk mengindikasikan besarnya kebutuhan masyarakat akan produk tersebut. Dalam rangka melindungi konsumen, maka perlu dikembangkan SNI untuk produk tersebut. Enam Produk yang mempunyai nilai impor besar dapat menjadi prioritas pengembangan SNI yaitu Wheat other than seed, other soya beans whether or not broken, other raw sugar refined white for pharmaceutical industry, maize ( corn ) other seeds, cane sugar, dan wheat or meslin flour.

c. Value Chain, dilihat dari value chain bagian downstream, lebih memberikan nilai tambah untuk produk dan/atau peningkatan kendali penjualan (sales control), juga meliputi perluasan ke dalam sektor jasa makanan (food service sector), industri makanan dan pertumbuhan distributor makanan, oleh karena itu standar yang dikembangkan tidak hanya hasil panen (crops) tetapi sampai produk jadi dari olehan hasil pertanian (final goods), kemudian dalam integrasi downstream berkembang kearah marketing, distribusi, dan jasa layanan (food services) maka perkembangan standar juga kearah food safety dan labelling.

d. Harmonisasi ztandar agro-based di ASEAN, perkembangan SNI juga dapat melihat pada kesepakatan harmonisasi standar agrobased di ASEAN, selain untuk produk/komoditi agrikultur juga berkembang ke arah food hygiene mulai dari preparation, processing, manufacturing, packaging, storing, transportation, distribution, handling dan sale dan supply.

\section{DAFTAR PUSTAKA}

1. Kusumo, H., Laporan Penelitian Kajian peluang indonesia dalam menghadapi integrasi ekonomi asean (asean economic integration), 2004.

2. NN, Data Industri dan Perdagangan Bulan Januari-Juni Tahun 2004, Pusat Data Industri, Departemen Perindustrian dan Perdagangan, Jakarta 2004

3. NN, Statistik Perdagangan Luar Negeri 2003, Badan Pusat Statistik, Jakarta, 2003

4. NN, Senarai Nasional Indonesia 2004, Badan Standardisasi Nasional, Jakarta

5. NN, Assessment of agro-based and fishery product sector in the area of standards and conformance, ASEAN Secretariat, 2004

6. Kajian kondisi Industri dan Perdagangan Produk Domestik, Sektor Pertanian, Perkebunan dan Hasil Hutan, Puslitbang, Badan Standardisasi

7. Nasional, 2004

\section{BIODATA}

Muti Sophira Hilman, dilahirkan di Bandung tahun 1974. Penulis adalah Asisten Peneliti Muda yang menamatkan pendidikan di Universitas Padjajaran, jurusan Biologi. Saat ini penulis bekerja di Badan Standardisasi Nasional sebagai staf pada Pusat Penelitian dan Pengembangan Standardisasi BSN

Ellia Kristiningrum, dilahirkan di Sukoharjo, 20 Februari 1981. Penulis menamatkan S1 jurusan Teknik Kimia di Universitas Pembangunan Nasional "Veteran" Yogyakarta. Saat ini penulis bekerja sebagai staf di Pusat Penelitian dan pengembangan Standardisasi, Badan Standardisasi Nasional. 


\section{Lampiran}

Pengelompokan Produk Berdasarkan Value Chain

\begin{tabular}{|c|c|c|c|c|c|c|c|c|}
\hline No & Hs & Uraian & Stock & $\begin{array}{c}\text { By } \\
\text { product }\end{array}$ & $\begin{array}{l}\text { Pro- } \\
\text { duct }\end{array}$ & $\begin{array}{l}\text { Second } \\
\text { process }\end{array}$ & $\begin{array}{l}\text { Inter- } \\
\text { mediate }\end{array}$ & $\begin{array}{l}\text { Final } \\
\text { goods }\end{array}$ \\
\hline 1 & 151190000 & Other palm oil & & & & & & - \\
\hline 2 & 151110000 & Crude palm oil & & & & & - & \\
\hline 3 & 180100000 & $\begin{array}{l}\text { Cocoa beans, whole or } \\
\text { broken, rawor roasted }\end{array}$ & 串 & & & & & \\
\hline 4 & 151321000 & Crude oil of palm kernel & & & & & 市 & \\
\hline 5 & 090111300 & $\begin{array}{l}\text { Coffee,not roasted not } \\
\text { decaffeinaterobusta oib }\end{array}$ & - & & & & & \\
\hline 6 & 151311000 & Crude oil of copra & & & & & 市 & \\
\hline 7 & 180400000 & $\begin{array}{l}\text { Cocoa butter, fat and } \\
\text { oil. }\end{array}$ & & & & & $=$ & \\
\hline 8 & 240220900 & Other cigarettes & & & & & & - \\
\hline 9 & 151790910 & $\begin{array}{l}\text { Other edible mixture of } \\
\text { vegetableorigin }\end{array}$ & & & 柿 & & & \\
\hline 10 & 151329000 & Other palm kernel oil & & & & & & 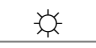 \\
\hline 11 & 200820300 & $\begin{array}{l}\text { Pineapples in syrup and } \\
\text { in airtight containers }\end{array}$ & & & & & & $=$ \\
\hline 12 & 090240200 & $\begin{array}{l}\text { Other black tea } \\
\text { (fermeted) dust }\end{array}$ & & - & & & & \\
\hline 13 & 151620100 & $\begin{array}{l}\text { Vegetable fats \& oil >= } \\
10 \mathrm{~kg}\end{array}$ & & & & & $=$ & \\
\hline 14 & 180500000 & $\begin{array}{l}\text { Cocoa powder, not } \\
\text { containing addedsugar / } \\
\text { other sweetening matter }\end{array}$ & & & 柿- & & & \\
\hline 15 & 090111200 & $\begin{array}{l}\text { Coffee,not roasted not } \\
\text { decaffeinatearabica wib }\end{array}$ & 串 & & & & & \\
\hline 16 & 080290120 & Areca nuts shelled & & & 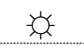 & & & \\
\hline 17 & 151319000 & Other copra oil & & & & & & - \\
\hline 18 & 240110900 & $\begin{array}{l}\text { Tobacco, not } \\
\text { stemmed/stripped of } \\
\text { other than virginia }\end{array}$ & & & - & & & \\
\hline 19 & 170490120 & Not medicated sweets & & & & & 市 & \\
\hline 20 & 151710900 & $\begin{array}{l}\text { Margarine, excl. Liquid } \\
\text { margarinein other } \\
\text { container }\end{array}$ & & & & & & 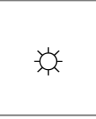 \\
\hline 21 & 090230000 & $\begin{array}{l}\text { Black tea (fermented) } \\
\text { and partlyfermented }\end{array}$ & & & 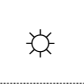 & & & \\
\hline 22 & 190530100 & Sweet biscuits & & & & & & 安 \\
\hline 23 & 090700100 & Cloves & & & & & & - \\
\hline 24 & 190219900 & $\begin{array}{l}\text { Other paste not } \\
\text { containing eggs }\end{array}$ & & & & & $=$ & \\
\hline 25 & 090411390 & $\begin{array}{l}\text { Black pepper, crushed } \\
\text { or ground }\end{array}$ & & & 妨- & & & \\
\hline 26 & 240120900 & $\begin{array}{l}\text { Tabacco, partly or } \\
\text { wholly } \\
\text { stemmed/stripped of } \\
\text { other than virginia }\end{array}$ & & & - & & & \\
\hline 27 & 090411290 & $\begin{array}{l}\text { White pepper, crushed } \\
\text { or ground }\end{array}$ & & & 婄- & & & \\
\hline 28 & 090810200 & Nutmeg shelled & & & 梠 & & & \\
\hline
\end{tabular}




\begin{tabular}{|c|c|c|c|c|c|c|c|c|}
\hline No & Hs & Uraian & Stock & $\begin{array}{c}\text { By } \\
\text { product }\end{array}$ & $\begin{array}{l}\text { Pro- } \\
\text { duct }\end{array}$ & $\begin{array}{l}\text { Second } \\
\text { process }\end{array}$ & $\begin{array}{l}\text { Inter- } \\
\text { mediate }\end{array}$ & $\begin{array}{l}\text { Final } \\
\text { goods }\end{array}$ \\
\hline 29 & 140120100 & $\begin{array}{l}\text { Rattan mixed, roughly } \\
\text { rubbed, unwashed, } \\
\text { smoked or sulphured }\end{array}$ & & & - & & & \\
\hline 30 & 090610000 & $\begin{array}{l}\text { Cinnamon \& cinnamon- } \\
\text { tree flowersneither } \\
\text { crushed nor ground }\end{array}$ & 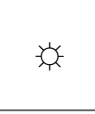 & & & & & \\
\hline 31 & 080131000 & Cashew nut in shell & 家 & & & & & \\
\hline 32 & 090500100 & Vanilla whole & 家 & & & & & \\
\hline 33 & 121220100 & Seaweeds & 安 & & & & & \\
\hline 34 & 200310100 & $\begin{array}{l}\text { Mushrooms in airtight } \\
\text { containers }\end{array}$ & & & & & & 串 \\
\hline 35 & 190230000 & Other pasta & & & & & 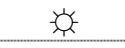 & \\
\hline 36 & 240120100 & $\begin{array}{l}\text { Tabacco, partly or } \\
\text { wholly } \\
\text { stemmed/stripped } \\
\text { virginia type flue cured }\end{array}$ & & & 㔔 & & & \\
\hline 37 & 200940990 & $\begin{array}{l}\text { Pineapple juice not for } \\
\text { retail sale }\end{array}$ & & & & & & $=$ \\
\hline 38 & 080111000 & Coconut desiccated & & & 案 & & & \\
\hline 39 & 090500900 & Other vanilla & & & 唯 & & & \\
\hline 40 & 210390900 & $\begin{array}{l}\text { Other sauces \& } \\
\text { preparation there of }\end{array}$ & & & & & 家 & \\
\hline 41 & 210111000 & $\begin{array}{l}\text { Extracts, essences and } \\
\text { concentrates of coffee }\end{array}$ & & & & & 凉 & \\
\hline 42 & 170490990 & $\begin{array}{l}\text { Other confectionary } \\
\text { sugar }\end{array}$ & & & & & & 家 \\
\hline 43 & 180632000 & $\begin{array}{l}\text { Oth chocolate in } \\
\text { blocks,slabs/barsnot } \\
\text { filled }\end{array}$ & & & & & & 安 \\
\hline 44 & 152000000 & $\begin{array}{l}\text { Glycerol, crude; glycerol } \\
\text { watersand glycerol lyes }\end{array}$ & & & & & 串 & \\
\hline 45 & 110100000 & Wheat or meslin flour. & & & & & $=$ & \\
\hline 46 & 180320000 & $\begin{array}{l}\text { Cocoa paste } \\
\text { wholly/partly defatted }\end{array}$ & & & & & $=$ & \\
\hline 47 & 240210000 & $\begin{array}{l}\text { Cigars, cheroots and } \\
\text { cigarillos,containing } \\
\text { tobacco }\end{array}$ & & & & & & 家 \\
\hline 48 & 151000000 & $\begin{array}{l}\text { Other oils and their } \\
\text { fractions,obtained solely } \\
\text { from olives }\end{array}$ & & & & & 安 & \\
\hline 49 & 090111900 & $\begin{array}{l}\text { Other coffee, not roasted } \\
\text { notdecaffeinated }\end{array}$ & 安 & & & & & \\
\hline 50 & 140410300 & Gambir & 家 & & & & & \\
\hline
\end{tabular}

